\title{
Acetylcholine receptors (muscarinic) in GtoPdb v.2021.2
}

Nigel J. M. Birdsall ${ }^{1}$, Sophie Bradley ${ }^{2}$, David A. Brown ${ }^{3}$, Noel J. Buckley ${ }^{4}$, R.A. John Challiss ${ }^{2}$, Arthur Christopoulos $^{5}$, Richard M. Eglen ${ }^{6}$, Frederick Ehlert ${ }^{7}$, Christian C. Felder ${ }^{8}$, Rudolf Hammer ${ }^{9}$, Heinz J. Kilbinger ${ }^{10}$, Günter Lambrecht ${ }^{11}$, Chris Langmead ${ }^{5}$, Fred Mitchelson ${ }^{12}$, Ernst Mutschler ${ }^{11}$, Neil M. Nathanson ${ }^{13}$, Roy D. Schwarz ${ }^{14}$, David Thal ${ }^{5}$, Andrew B. Tobin ${ }^{2}$, Celine Valant ${ }^{5}$ and Jurgen Wess ${ }^{15}$

1. Francis Crick Institute, UK

2. University of Leicester, UK

3. University College London, UK

4. King's College London, UK

5. Monash University, Australia

6. PerkinElmer, UK

7. University of California Irvine, USA

8. Lilly Research Laboratories, USA

9. Nippon Boehringer Ingleheim, Japan

10. University of Mainz, Germany

11. University of Frankfurt, Germany

12. University of Melbourne, Australia

13. University of Washington, USA

14. Pfizer, USA

15. National Institutes of Health, USA

\begin{abstract}
Muscarinic acetylcholine receptors (mAChRs) (nomenclature as agreed by the NC-IUPHAR Subcommittee on Muscarinic Acetylcholine Receptors [50]) are activated by the endogenous agonist acetylcholine. All five (M1-M5) mAChRs are ubiquitously expressed in the human body and are therefore attractive targets for many disorders. Functionally, $\mathrm{M}_{1}, \mathrm{M}_{3}$, and $\mathrm{M}_{5} \mathrm{mAChRs}$ preferentially couple to $G_{\mathrm{q} / 11}$ proteins, whilst $M_{2}$ and $M_{4} m A C h R s$ predominantly couple to $G_{i / o}$ proteins. Both agonists and antagonists of $\mathrm{mAChRs}$ are clinically approved drugs, including pilocarpine for the treatment of elevated intra-ocular pressure and glaucoma, and atropine for the treatment of bradycardia and poisoning by muscarinic agents such as organophosphates. I
\end{abstract}

\section{Contents}

This is a citation summary for Acetylcholine receptors (muscarinic) in the Guide to Pharmacology database (GtoPdb). It exists purely as an adjunct to the database to facilitate the recognition of citations to and from the database by citation analyzers. Readers will almost certainly want to visit the relevant sections of the database which are given here under database links.

GtoPdb is an expert-driven guide to pharmacological targets and the substances that act on them. GtoPdb is a reference work which is most usefully represented as an on-line database. As in any publication this work should be appropriately cited, and the papers it cites should also be recognized. This document provides a citation for the relevant parts of the database, and also provides a reference list for the research cited by those parts. For further details see [39].

Please note that the database version for the citations given in GtoPdb are to the most recent preceding version in which the family or its subfamilies and targets were substantially changed. The links below are to the current version. If you need to consult the cited version, rather than the most recent version, please contact the GtoPdb curators.

\section{Database links}


https://www.guidetopharmacology.org/GRAC/FamilyDisplayForward?familyId=2

Introduction to Acetylcholine receptors (muscarinic)

https://www.guidetopharmacology.org/GRAC/FamilyIntroductionForward?familyId =2

Receptors
$\mathrm{M}_{1}$ receptor
https://www.guidetopharmacology.org/GRAC/ObjectDisplayForward?objectId=13
$\mathrm{M}_{2}$ receptor
https://www.guidetopharmacology.org/GRAC/ObjectDisplayForward?objectId=14
$\mathrm{M}_{3}$ receptor
https://www.guidetopharmacology.org/GRAC/ObjectDisplayForward?objectId=15
$\mathrm{M}_{4}$ receptor
https://www.guidetopharmacology.org/GRAC/ObjectDisplayForward?objectId=16
$\mathrm{M}_{5}$ receptor
https://www.guidetopharmacology.org/GRAC/ObjectDisplayForward?objectId=17

\section{References}

1. Abdul-Ridha A, Lane JR, Mistry SN, López L, Sexton PM, Scammells PJ, Christopoulos A and Canals M. (2014) Mechanistic insights into allosteric structure-function relationships at the M1 muscarinic acetylcholine receptor. J Biol Chem 289: 33701-11 [PMID:25326383]

2. Abdul-Ridha A, López L, Keov P, Thal DM, Mistry SN, Sexton PM, Lane JR, Canals M and Christopoulos A. (2014) Molecular determinants of allosteric modulation at the M1 muscarinic acetylcholine receptor. J Biol Chem 289: 6067-79 [PMID:24443568]

3. Aihara T, Fujishita T, Kanatani K, Furutani K, Nakamura E, Taketo MM, Matsui M, Chen D and Okabe S. (2003) Impaired gastric secretion and lack of trophic responses to hypergastrinemia in M3 muscarinic receptor knockout mice. Gastroenterology 125: 1774-84 [PMID:14724830]

4. Aihara T, Nakamura Y, Taketo MM, Matsui M and Okabe S. (2005) Cholinergically stimulated gastric acid secretion is mediated by $\mathrm{M}(3)$ and $\mathrm{M}(5)$ but not $\mathrm{M}(1)$ muscarinic acetylcholine receptors in mice. Am J Physiol Gastrointest Liver Physiol 288: G1199-207 [PMID:15691866]

5. Akbulut H, Gören Z, Iskender E, Eraslan A, Ozdemir O and Oktay S. (1999) Subtypes of muscarinic receptors in rat duodenum: a comparison with rabbit vas deferens, rat atria, guineapig ileum and gallbladder by using imperialine. Gen Pharmacol 32: 505-11 [PMID:10323493]

6. Anagnostaras SG, Murphy GG, Hamilton SE, Mitchell SL, Rahnama NP, Nathanson NM and Silva AJ. (2003) Selective cognitive dysfunction in acetylcholine M1 muscarinic receptor mutant mice. Nat Neurosci 6: 51-8 [PMID:12483218]

7. Anderson DJ and McKinney M. (1988) Muscarinic M2 receptor-mediated cyclic AMP reduction in mechanically dissociated rat cortex. Brain Res 475: 28-34 [PMID:2850835]

8. Araya R, Noguchi T, Yuhki M, Kitamura N, Higuchi M, Saido TC, Seki K, Itohara S, Kawano M and Tanemura K et al.. (2006) Loss of M5 muscarinic acetylcholine receptors leads to cerebrovascular and neuronal abnormalities and cognitive deficits in mice. Neurobiol Dis 24: 334-44 [PMID:16956767]

9. Auerbach SS and DrugMatrix ${ }^{\circledR}$ and ToxFX ${ }^{\circledR}$ Coordinator National Toxicology Program. National Toxicology Program: Dept of Health and Human Services.

10. Avlani VA, Gregory KJ, Morton CJ, Parker MW, Sexton PM and Christopoulos A. (2007) Critical role for the second extracellular loop in the binding of both orthosteric and allosteric $\mathrm{G}$ proteincoupled receptor ligands. J Biol Chem 282: 25677-86 [PMID:17591774]

11. Avlani VA, Langmead CJ, Guida E, Wood MD, Tehan BG, Herdon HJ, Watson JM, Sexton PM and Christopoulos A. (2010) Orthosteric and allosteric modes of interaction of novel selective agonists of the M1 muscarinic acetylcholine receptor. Mol Pharmacol 78: 94-104 [PMID:20413650]

12. Badner JA, Yoon SW, Turner G, Bonner TI and Detera-Wadleigh SD. (1995) Multipoint genetic linkage analysis of the $\mathrm{m} 2$ human muscarinic receptor gene. Mamm Genome 6: 489-90 [PMID:7579899]

13. Baghdoyan HA. (1997) Location and quantification of muscarinic receptor subtypes in rat pons: implications for REM sleep generation. Am J Physiol 273: R896-904 [PMID:9321865]

14. Basile AS, Fedorova I, Zapata A, Liu X, Shippenberg T, Duttaroy A, Yamada M and Wess J. (2002) Deletion of the M5 muscarinic acetylcholine receptor attenuates morphine reinforcement and withdrawal but not morphine analgesia. Proc Natl Acad Sci USA 99: 11452-7 [PMID:12154229]

15. Baumgold J, Dyer K, Falcone JF and Bymaster FP. (1995) Comparison of second-messenger responses to muscarinic receptor stimulation in M1-transfected A9 L cells. Cell Signal 7: 39-43 [PMID:7756109]

16. Berizzi AE, Gentry PR, Rueda P, Den Hoedt S, Sexton PM, Langmead CJ and Christopoulos A. (2016) Molecular Mechanisms of Action of M5 Muscarinic Acetylcholine Receptor Allosteric 
Modulators. Mol Pharmacol 90: 427-36 [PMID:27461343]

17. Bernardini N, Roza C, Sauer SK, Gomeza J, Wess J and Reeh PW. (2002) Muscarinic M2 receptors on peripheral nerve endings: a molecular target of antinociception. J Neurosci 22 : RC229 [PMID:12045234]

18. Berrie CP, Birdsall NJ, Hulme EC, Keen M and Stockton JM. (1984) Solubilization and characterization of guanine nucleotide-sensitive muscarinic agonist binding sites from rat myocardium. Br J Pharmacol 82: 853-61 [PMID:6478115]

19. Beshore DC, N Di Marco C, Chang RK, Greshock TJ, Ma L, Wittmann M, Seager MA, Koeplinger KA, Thompson CD and Fuerst J et al.. (2018) MK-7622: A First-in-Class $\mathrm{M}_{1}$ Positive Allosteric Modulator Development Candidate. ACS Med Chem Lett 9: 652-656 [PMID:30034595]

20. Biddlecome GH, Berstein G and Ross EM. (1996) Regulation of phospholipase C-beta1 by Gq and $\mathrm{m} 1$ muscarinic cholinergic receptor. Steady-state balance of receptor-mediated activation and GTPase-activating protein-promoted deactivation. J Biol Chem 271: 7999-8007 [PMID:8626481]

21. Birdsall NJ, Farries T, Gharagozloo P, Kobayashi S, Lazareno S and Sugimoto M. (1999) Subtype-selective positive cooperative interactions between brucine analogs and acetylcholine at muscarinic receptors: functional studies. Mol Pharmacol 55: 778-86 [PMID:10101037]

22. Birdsall NJ and Lazareno S. (2005) Allosterism at muscarinic receptors: ligands and mechanisms. Mini Rev Med Chem 5: 523-43 [PMID:15974931]

23. Bognar IT, Beinhauer B, Kann P and Fuder H. (1990) Different muscarinic receptors mediate autoinhibition of acetylcholine release and vagally-induced vasoconstriction in the rat isolated perfused heart. Naunyn Schmiedebergs Arch Pharmacol 341: 279-87 [PMID:2333099]

24. Bolden C, Cusack B and Richelson E. (1992) Antagonism by antimuscarinic and neuroleptic compounds at the five cloned human muscarinic cholinergic receptors expressed in Chinese hamster ovary cells. J Pharmacol Exp Ther 260: 576-80 [PMID:1346637]

25. Bonner TI. (1989) The molecular basis of muscarinic receptor diversity. Trends Neurosci 12: 148-51 [PMID:2470172]

26. Bonner TI, Buckley NJ, Young AC and Brann MR. (1987) Identification of a family of muscarinic acetylcholine receptor genes. Science 237: 527-32 [PMID:3037705]

27. Bonner TI, Modi WS, Seuanez HN and O'Brien SJ. (1991) Chromosomal mapping of the five human genes encoding muscarinic acetylcholine receptors. Cytogenet Cell Genet 58: 1850-1851

28. Bonner TI, Young AC, Brann MR and Buckley NJ. (1988) Cloning and expression of the human and rat m5 muscarinic acetylcholine receptor genes. Neuron 1: 403-10 [PMID:3272174]

29. Boudinot E, Yamada M, Wess J, Champagnat J and Foutz AS. (2004) Ventilatory pattern and chemosensitivity in M1 and M3 muscarinic receptor knockout mice. Respir Physiol Neurobiol 139: 237-45 [PMID:15122990]

30. Brady AE, Jones CK, Bridges TM, Kennedy JP, Thompson AD, Heiman JU, Breininger ML, Gentry $\mathrm{PR}$, Yin $\mathrm{H}$ and Jadhav SB et al.. (2008) Centrally active allosteric potentiators of the M4 muscarinic acetylcholine receptor reverse amphetamine-induced hyperlocomotor activity in rats. J Pharmacol Exp Ther 327: 941-53 [PMID:18772318]

31. Bridges TM, Marlo JE, Niswender CM, Jones CK, Jadhav SB, Gentry PR, Plumley HC, Weaver CD, Conn PJ and Lindsley CW. (2009) Discovery of the first highly M5-preferring muscarinic acetylcholine receptor ligand, an M5 positive allosteric modulator derived from a series of 5trifluoromethoxy N-benzyl isatins. J Med Chem 52: 3445-8 [PMID:19438238]

32. Broad LM, Sanger HE, Mogg AJ, Colvin EM, Zwart R, Evans DA, Pasqui F, Sher E, Wishart GN and Barth VN et al.. (2019) Identification and pharmacological profile of SPP1, a potent, functionally selective and brain penetrant agonist at muscarinic $\mathrm{M}_{1}$ receptors. BrJ Pharmacol 176: 110-126 [PMID:30276808]

33. Brodde OE and Michel MC. (1999) Adrenergic and muscarinic receptors in the human heart. Pharmacol Rev 51: 651-90 [PMID:10581327]

34. Brudzynski SM, McLachlan RS and Girvin JP. (1991) Involvement of M1 and M2 muscarinic receptors of the basal forebrain in cholinergically mediated changes in the rat locomotion. Prog Neuropsychopharmacol Biol Psychiatry 15: 279-84 [PMID:1871329]

35. Bräuner-Osborne H and Brann MR. (1996) Pharmacology of muscarinic acetylcholine receptor subtypes (m1-m5): high throughput assays in mammalian cells. Eur J Pharmacol 295: 93-102 [PMID:8925880]

36. Bräuner-Osborne H, Ebert B, Brann MR, Falch E and Krogsgaard-Larsen P. (1996) Functional partial agonism at cloned human muscarinic acetylcholine receptors. Eur J Pharmacol 313: 14550 [PMID:8905341]

37. Buckley NJ, Bonner TI, Buckley CM and Brann MR. (1989) Antagonist binding properties of five cloned muscarinic receptors expressed in CHO-K1 cells. Mol Pharmacol 35: 469-76 [PMID:2704370]

38. Budd DC, Rae A and Tobin AB. (1999) Activation of the mitogen-activated protein kinase pathway by a $\mathrm{Gq} / 11$-coupled muscarinic receptor is independent of receptor internalization. $J$ Biol Chem 274: 12355-60 [PMID:10212206] 
39. Buneman P, Christie G, Davies JA, Dimitrellou R, Harding SD, Pawson AJ, Sharman JL and Wu Y. (2020) Why data citation isn't working, and what to do about it Database 2020 [PMID:32367113]

40. Burke RE. (1986) The relative selectivity of anticholinergic drugs for the M1 and M2 muscarinic receptor subtypes. Mov Disord 1: 135-44 [PMID:2904117]

41. Bymaster FP, Carter PA, Zhang L, Falcone JF, Stengel PW, Cohen ML, Shannon HE, Gomeza J, Wess J and Felder CC. (2001) Investigations into the physiological role of muscarinic M2 and M4 muscarinic and M4 receptor subtypes using receptor knockout mice. Life Sci 68: 2473-9 [PMID:11392615]

42. Bymaster FP, Felder C, Ahmed S and McKinzie D. (2002) Muscarinic receptors as a target for drugs treating schizophrenia. Curr Drug Targets CNS Neurol Disord 1: 163-81 [PMID:12769625]

43. Bymaster FP, McKinzie DL, Felder CC and Wess J. (2003) Use of M1-M5 muscarinic receptor knockout mice as novel tools to delineate the physiological roles of the muscarinic cholinergic system. Neurochem Res 28: 437-42 [PMID:12675128]

44. Böhme TM, Keim C, Kreutzmann K, Linder M, Dingermann T, Dannhardt G, Mutschler E and Lambrecht G. (2003) Structure-activity relationships of dimethindene derivatives as new M2selective muscarinic receptor antagonists. J Med Chem 46: 856-67 [PMID:12593665]

45. Caccamo A, Oddo S, Billings LM, Green KN, Martinez-Coria H, Fisher A and LaFerla FM. (2006) M1 receptors play a central role in modulating AD-like pathology in transgenic mice. Neuron 49: 671-82 [PMID:16504943]

46. Canals M, Lane JR, Wen A, Scammells PJ, Sexton PM and Christopoulos A. (2012) A MonodWyman-Changeux mechanism can explain G protein-coupled receptor (GPCR) allosteric modulation. J Biol Chem 287: 650-9 [PMID:22086918]

47. Candell LM, Yun SH, Tran LL and Ehlert FJ. (1990) Differential coupling of subtypes of the muscarinic receptor to adenylate cyclase and phosphoinositide hydrolysis in the longitudinal muscle of the rat ileum. Mol Pharmacol 38: 689-97 [PMID:2172776]

48. Carr BJ, Mihara K, Ramachandran R, Saifeddine M, Nathanson NM, Stell WK and Hollenberg MD. (2018) Myopia-Inhibiting Concentrations of Muscarinic Receptor Antagonists Block Activation of Alpha2A-Adrenoceptors In Vitro. Invest Ophthalmol Vis Sci 59: 2778-2791 [PMID:29860464]

49. Caulfield MP. (1993) Muscarinic receptors--characterization, coupling and function. Pharmacol Ther 58: 319-79 [PMID:7504306]

50. Caulfield MP and Birdsall NJ. (1998) International Union of Pharmacology. XVII. Classification of muscarinic acetylcholine receptors. Pharmacol Rev 50: 279-90 [PMID:9647869]

51. Cembala TM, Sherwin JD, Tidmarsh MD, Appadu BL and Lambert DG. (1998) Interaction of neuromuscular blocking drugs with recombinant human m1-m5 muscarinic receptors expressed in Chinese hamster ovary cells. Br J Pharmacol 125: 1088-94 [PMID:9846649]

52. Ch'ng SS, Walker AJ, McCarthy M, Le TK, Thomas N, Gibbons A, Udawela M, Kusljic S, Dean B and Gogos A. (2020) The Impact of Removal of Ovarian Hormones on Cholinergic Muscarinic Receptors: Examining Prepulse Inhibition and Receptor Binding. Brain Sci 10 [PMID:32079174]

53. Chan WY, McKinzie DL, Bose S, Mitchell SN, Witkin JM, Thompson RC, Christopoulos A, Lazareno S, Birdsall NJ and Bymaster FP et al.. (2008) Allosteric modulation of the muscarinic M4 receptor as an approach to treating schizophrenia. Proc Natl Acad Sci USA 105: 10978-83 [PMID:18678919]

54. Chariot J, De la Tour J, Vaille C and Rozé C. (1987) Comparative effects of pirenzepine and atropine on pancreatic secretion in conscious rats. Arch Int Pharmacodyn Ther 285: 158-65 [PMID:3579423]

55. Cheng K, Khurana S, Chen Y, Kennedy RH, Zimniak P and Raufman JP. (2002) Lithocholylcholine, a bile acid/acetylcholine hybrid, is a muscarinic receptor antagonist. $J$ Pharmacol Exp Ther 303: 29-35 [PMID:12235229]

56. Chernyavsky AI, Arredondo J, Wess J, Karlsson E and Grando SA. (2004) Novel signaling pathways mediating reciprocal control of keratinocyte migration and wound epithelialization through M3 and M4 muscarinic receptors. J Cell Biol 166: 261-72 [PMID:15263021]

57. Chernyavsky AI, Nguyen VT, Arredondo J, Ndoye A, Zia S, Wess J and Grando SA. (2003) The M4 muscarinic receptor-selective effects on keratinocyte crawling locomotion. Life Sci 72: 206973 [PMID:12628458]

58. Chintoh A, Fulton J, Koziel N, Aziz M, Sud M and Yeomans JS. (2003) Role of cholinergic receptors in locomotion induced by scopolamine and oxotremorine-M. Pharmacol Biochem Behav 76: 53-61 [PMID:13679217]

59. Christopoulos A, Grant MK, Ayoubzadeh N, Kim ON, Sauerberg P, Jeppesen L and El-Fakahany EE. (2001) Synthesis and pharmacological evaluation of dimeric muscarinic acetylcholine receptor agonists. J Pharmacol Exp Ther 298: 1260-8 [PMID:11504829]

60. Christopoulos A, Pierce TL, Sorman JL and El-Fakahany EE. (1998) On the unique binding and activating properties of xanomeline at the M1 muscarinic acetylcholine receptor. Mol Pharmacol 
53: 1120-30 [PMID:9614217]

61. Christopoulos A, Sorman JL, Mitchelson F and El-Fakahany EE. (1999) Characterization of the subtype selectivity of the allosteric modulator heptane-1,7-bis-(dimethyl-3'-phthalimidopropyl) ammonium bromide (C7/3-phth) at cloned muscarinic acetylcholine receptors. Biochem Pharmacol 57: 171-9 [PMID:9890565]

62. Christopoulos A and Wilson K. (2001) Interaction of anandamide with the M(1) and M(4) muscarinic acetylcholine receptors. Brain Res 915: 70-8 [PMID:11578621]

63. Clark AL and Mitchelson F. (1976) The inhibitory effect of gallamine on muscarinic receptors. $\mathrm{Br}$ J Pharmacol 58: 323-31 [PMID:990587]

64. Conn PJ, Jones CK and Lindsley CW. (2009) Subtype-selective allosteric modulators of muscarinic receptors for the treatment of CNS disorders. Trends Pharmacol Sci 30: 148-55 [PMID:19201489]

65. Cortés R, Probst A, Tobler HJ and Palacios JM. (1986) Muscarinic cholinergic receptor subtypes in the human brain. II. Quantitative autoradiographic studies. Brain Res 362: 239-53 [PMID:3753655]

66. Croy CH, Chan WY, Castetter AM, Watt ML, Quets AT and Felder CC. (2016) Characterization of PCS1055, a novel muscarinic M4 receptor antagonist. Eur J Pharmacol 782: 70-6 [PMID:27085897]

67. Croy CH, Schober DA, Xiao H, Quets A, Christopoulos A and Felder CC. (2014) Characterization of the novel positive allosteric modulator, LY2119620, at the muscarinic M(2) and M(4) receptors. Mol Pharmacol 86: 106-15 [PMID:24807965]

68. D'Agostino G, Barbieri A, Chiossa E and Tonini M. (1997) M4 muscarinic autoreceptor-mediated inhibition of -3H-acetylcholine release in the rat isolated urinary bladder. J Pharmacol Exp Ther 283: 750-6 [PMID:9353395]

69. D'Agostino G, Bolognesi ML, Lucchelli A, Vicini D, Balestra B, Spelta V, Melchiorre C and Tonini M. (2000) Prejunctional muscarinic inhibitory control of acetylcholine release in the human isolated detrusor: involvement of the M4 receptor subtype. BrJ Pharmacol 129: 493-500 [PMID:10711347]

70. Davoren JE, Lee CW, Garnsey M, Brodney MA, Cordes J, Dlugolenski K, Edgerton JR, Harris AR, Helal CJ and Jenkinson S et al.. (2016) Discovery of the Potent and Selective M1 PAM-Agonist N[(3R,4S)-3-Hydroxytetrahydro-2H-pyran-4-yl]-5-methyl-4-[4-(1,3-thiazol-4-yl)benzyl]pyridine-2carboxamide (PF-06767832): Evaluation of Efficacy and Cholinergic Side Effects. J Med Chem 59: 6313-28 [PMID:27275946]

71. Degroot A and Nomikos GG. (2006) Genetic deletion of muscarinic M4 receptors is anxiolytic in the shock-probe burying model. Eur J Pharmacol 531: 183-6 [PMID:16455072]

72. Del Bello F, Barocelli E, Bertoni S, Bonifazi A, Camalli M, Campi G, Giannella M, Matucci R, Nesi $\mathrm{M}$ and Pigini $\mathrm{M}$ et al.. (2012) 1,4-dioxane, a suitable scaffold for the development of novel $\mathrm{M}_{3}$ muscarinic receptor antagonists. J Med Chem 55: 1783-7 [PMID:22243489]

73. Disse B, Reichl R, Speck G, Traunecker W, Ludwig Rominger KL and Hammer R. (1993) Ba 679 BR, a novel long-acting anticholinergic bronchodilator. Life Sci 52: 537-44 [PMID:8441333]

74. Dong GZ, Kameyama K, Rinken A and Haga T. (1995) Ligand binding properties of muscarinic acetylcholine receptor subtypes (m1-m5) expressed in baculovirus-infected insect cells. $J$ Pharmacol Exp Ther 274: 378-84 [PMID:7616422]

75. Dowling MR and Charlton SJ. (2006) Quantifying the association and dissociation rates of unlabelled antagonists at the muscarinic M3 receptor. BrJ Pharmacol 148: 927-37 [PMID:16847442]

76. Duttaroy A, Gomeza J, Gan JW, Siddiqui N, Basile AS, Harman WD, Smith PL, Felder CC, Levey AI and Wess J. (2002) Evaluation of muscarinic agonist-induced analgesia in muscarinic acetylcholine receptor knockout mice. Mol Pharmacol 62: 1084-93 [PMID:12391271]

77. Duttaroy A, Zimliki CL, Gautam D, Cui Y, Mears D and Wess J. (2004) Muscarinic stimulation of pancreatic insulin and glucagon release is abolished in $\mathrm{m} 3$ muscarinic acetylcholine receptordeficient mice. Diabetes 53: 1714-20 [PMID:15220195]

78. Dörje F, Wess J, Lambrecht G, Tacke R, Mutschler E and Brann MR. (1991) Antagonist binding profiles of five cloned human muscarinic receptor subtypes. J Pharmacol Exp Ther 256: 727-33 [PMID:1994002]

79. Eglen RM. (2005) Muscarinic receptor subtype pharmacology and physiology. Prog Med Chem 43: 105-36 [PMID:15850824]

80. Eglen RM, Hegde SS and Watson N. (1996) Muscarinic receptor subtypes and smooth muscle function. Pharmacol Rev 48: 531-65 [PMID:8981565]

81. Ehlert FJ, Delen FM, Yun SH, Friedman DJ and Self DW. (1989) Coupling of subtypes of the muscarinic receptor to adenylate cyclase in the corpus striatum and heart. J Pharmacol Exp Ther 251: 660-71 [PMID:2810116]

82. Ehlert FJ, Griffin MT, Abe DM, Vo TH, Taketo MM, Manabe T and Matsui M. (2005) The M2 muscarinic receptor mediates contraction through indirect mechanisms in mouse urinary bladder. J Pharmacol Exp Ther 313: 368-78 [PMID:15608083] 
83. Ehlert FJ, Griffin MT and Glidden PF. (1996) The interaction of the enantiomers of aceclidine with subtypes of the muscarinic receptor. J Pharmacol Exp Ther 279: 1335-44 [PMID:8968358]

84. Ehlert FJ, Griffin MT, Sawyer GW and Bailon R. (1999) A simple method for estimation of agonist activity at receptor subtypes: comparison of native and cloned M3 muscarinic receptors in guinea pig ileum and transfected cells. J Pharmacol Exp Ther 289: 981-92 [PMID:10215678]

85. Ehlert FJ and Rathbun BE. (1990) Signaling through the muscarinic receptor-adenylate cyclase system of the heart is buffered against GTP over a range of concentrations. Mol Pharmacol 38: 148-58 [PMID:2370853]

86. Elhusseiny A and Hamel E. (2000) Muscarinic--but not nicotinic--acetylcholine receptors mediate a nitric oxide-dependent dilation in brain cortical arterioles: a possible role for the M5 receptor subtype. J Cereb Blood Flow Metab 20: 298-305 [PMID:10698067]

87. Esqueda EE, Gerstin Jr EH, Griffin MT and Ehlert FJ. (1996) Stimulation of cyclic AMP accumulation and phosphoinositide hydrolysis by M3 muscarinic receptors in the rat peripheral lung. Biochem Pharmacol 52: 643-58 [PMID:8759038]

88. Eveleigh P, Hulme EC, Schudt C and Birdsall NJ. (1989) The existence of stable enantiomers of telenzepine and their stereoselective interaction with muscarinic receptor subtypes. $\mathrm{Mol}$ Pharmacol 35: 477-83 [PMID:2704371]

89. Farde L, Suhara T, Halldin C, Nybäck H, Nakashima Y, Swahn CG, Karlsson P, Ginovart N, Bymaster FP and Shannon HE et al.. (1996) PET study of the M1-agonists [11C]xanomeline and [11C]butylthio-TZTP in monkey and man. Dementia 7: 187-95 [PMID:8835881]

90. Fargeas MJ, Fioramonti J and Buéno L. (1987) Central muscarinic control of the pattern of small intestinal motility in rats. Life Sci 40: 1709-15 [PMID:3561171]

91. Fernandez-Fernandez JM, Wanaverbecq N, Halley P, Caulfield MP and Brown DA. (1999) Selective activation of heterologously expressed G protein-gated K+ channels by M2 muscarinic receptors in rat sympathetic neurones. J Physiol (Lond.) 515 ( Pt 3): 631-7 [PMID:10066893]

92. Fernández-Fernández JM, Abogadie FC, Milligan G, Delmas P and Brown DA. (2001) Multiple pertussis toxin-sensitive G-proteins can couple receptors to GIRK channels in rat sympathetic neurons when expressed heterologously, but only native G(i)-proteins do so in situ. Eur J Neurosci 14: 283-92 [PMID:11553279]

93. Ferrari-Dileo G, Waelbroeck M, Mash DC and Flynn DD. (1994) Selective labeling and localization of the M4 (m4) muscarinic receptor subtype. Mol Pharmacol 46: 1028-35 [PMID:7808421]

94. Feuerstein TJ, Lehmann J, Sauermann W, van Velthoven V and Jackisch R. (1992) The autoinhibitory feedback control of acetylcholine release in human neocortex tissue. Brain Res 572: 64-71 [PMID:1611539]

95. Fink-Jensen A, Fedorova I, Wörtwein G, Woldbye DP, Rasmussen T, Thomsen M, Bolwig TG, Knitowski KM, McKinzie DL and Yamada M et al.. (2003) Role for M5 muscarinic acetylcholine receptors in cocaine addiction. J Neurosci Res 74: 91-6 [PMID:13130510]

96. Fisher JT, Vincent SG, Gomeza J, Yamada M and Wess J. (2004) Loss of vagally mediated bradycardia and bronchoconstriction in mice lacking M2 or M3 muscarinic acetylcholine receptors. FASEB J 18: 711-3 [PMID:14977875]

97. Forster GL, Yeomans JS, Takeuchi J and Blaha CD. (2002) M5 muscarinic receptors are required for prolonged accumbal dopamine release after electrical stimulation of the pons in mice. $J$ Neurosci 22: RC190 [PMID:11756520]

98. Forsythe SM, Kogut PC, McConville JF, Fu Y, McCauley JA, Halayko AJ, Liu HW, Kao A, Fernandes DJ and Bellam S et al.. (2002) Structure and transcription of the human $\mathrm{m} 3$ muscarinic receptor gene. Am J Respir Cell Mol Biol 26: 298-305 [PMID:11867338]

99. Fruchart-Gaillard C, Mourier G, Marquer C, Ménez A and Servent D. (2006) Identification of various allosteric interaction sites on M1 muscarinic receptor using 125I-Met35-oxidized muscarinic toxin 7. Mol Pharmacol 69: 1641-51 [PMID:16439611]

100. Gautam D, Gavrilova O, Jeon J, Pack S, Jou W, Cui Y, Li JH and Wess J. (2006) Beneficial metabolic effects of M3 muscarinic acetylcholine receptor deficiency. Cell Metab 4: 363-75 [PMID:17084710]

101. Gautam D, Han SJ, Duttaroy A, Mears D, Hamdan FF, Li JH, Cui Y, Jeon J and Wess J. (2007) Role of the M3 muscarinic acetylcholine receptor in beta-cell function and glucose homeostasis. Diabetes Obes Metab 9 Suppl 2: 158-69 [PMID:17919190]

102. Gautam D, Han SJ, Hamdan FF, Jeon J, Li B, Li JH, Cui Y, Mears D, Lu H and Deng C et al.. (2006) A critical role for beta cell M3 muscarinic acetylcholine receptors in regulating insulin release and blood glucose homeostasis in vivo. Cell Metab 3: 449-61 [PMID:16753580]

103. Gautam D, Heard TS, Cui Y, Miller G, Bloodworth L and Wess J. (2004) Cholinergic stimulation of salivary secretion studied with M1 and M3 muscarinic receptor single- and double-knockout mice. Mol Pharmacol 66: 260-7 [PMID:15266016]

104. Gentry PR, Kokubo M, Bridges TM, Cho HP, Smith E, Chase P, Hodder PS, Utley TJ, Rajapakse A and Byers F et al.. (2014) Discovery, synthesis and characterization of a highly muscarinic acetylcholine receptor (mAChR)-selective M5-orthosteric antagonist, VU0488130 (ML381): a 
novel molecular probe. ChemMedChem 9: 1677-82 [PMID:24692176]

105. Gentry PR, Kokubo M, Bridges TM, Kett NR, Harp JM, Cho HP, Smith E, Chase P, Hodder PS and Niswender CM et al.. (2013) Discovery of the first M5-selective and CNS penetrant negative allosteric modulator (NAM) of a muscarinic acetylcholine receptor: (S)-9b-(4-chlorophenyl)-1(3,4-difluorobenzoyl)-2,3-dihydro-1H-imidazo[2,1-a]isoindol-5(9bH)-one (ML375). J Med Chem 56: 9351-5 [PMID:24164599]

106. Gentry PR, Kokubo M, Bridges TM, Noetzel MJ, Cho HP, Lamsal A, Smith E, Chase P, Hodder PS and Niswender CM et al.. (2014) Development of a highly potent, novel M5 positive allosteric modulator (PAM) demonstrating CNS exposure: 1-((1H-indazol-5-yl)sulfoneyl)-N-ethyl-N-(2(trifluoromethyl)benzyl)piperidine-4-carboxamide (ML380). J Med Chem 57: 7804-10 [PMID:25147929]

107. Gerber DJ, Sotnikova TD, Gainetdinov RR, Huang SY, Caron MG and Tonegawa S. (2001) Hyperactivity, elevated dopaminergic transmission, and response to amphetamine in M1 muscarinic acetylcholine receptor-deficient mice. Proc Natl Acad Sci USA 98: 15312-7 [PMID:11752469]

108. Gillberg PG, Gordh Jr T, Hartvig P, Jansson I, Pettersson J and Post C. (1989) Characterization of the antinociception induced by intrathecally administered carbachol. Pharmacol Toxicol 64: 340-3 [PMID:2748539]

109. Gillberg PG, Sundquist S and Nilvebrant L. (1998) Comparison of the in vitro and in vivo profiles of tolterodine with those of subtype-selective muscarinic receptor antagonists. Eur J Pharmacol 349: 285-92 [PMID:9671109]

110. Gillette MU, Buchanan GF, Artinian L, Hamilton SE, Nathanson NM and Liu C. (2001) Role of the M1 receptor in regulating circadian rhythms. Life Sci 68: 2467-72 [PMID:11392614]

111. Gomeza J, Shannon H, Kostenis E, Felder C, Zhang L, Brodkin J, Grinberg A, Sheng H and Wess J. (1999) Pronounced pharmacologic deficits in M2 muscarinic acetylcholine receptor knockout mice. Proc Natl Acad Sci USA 96: 1692-7 [PMID:9990086]

112. Gomeza J, Zhang L, Kostenis E, Felder C, Bymaster F, Brodkin J, Shannon H, Xia B, Deng C and Wess J. (1999) Enhancement of D1 dopamine receptor-mediated locomotor stimulation in $\mathrm{M}(4)$ muscarinic acetylcholine receptor knockout mice. Proc Natl Acad Sci USA 96: 10483-8 [PMID:10468635]

113. Gomeza J, Zhang L, Kostenis E, Felder CC, Bymaster FP, Brodkin J, Shannon H, Xia B, Duttaroy A and Deng CX et al.. (2001) Generation and pharmacological analysis of M2 and M4 muscarinic receptor knockout mice. Life Sci 68: 2457-66 [PMID:11392613]

114. Goutagny R, Comte JC, Salvert D, Gomeza J, Yamada M, Wess J, Luppi PH and Fort P. (2005) Paradoxical sleep in mice lacking M3 and M2/M4 muscarinic receptors. Neuropsychobiology 52: 140-6 [PMID:16110248]

115. Grant MK and El-Fakahany EE. (2005) Persistent binding and functional antagonism by xanomeline at the muscarinic M5 receptor. J Pharmacol Exp Ther 315: 313-9 [PMID:16002459]

116. Grewal RP, Martinez M, Hoehe M, Bonner TI, Gershon ES and Detera-Wadleigh S. (1992) Genetic linkage mapping of the m4 human muscarinic receptor (CHRM4). Genomics 13: 239-40 [PMID:1577490]

117. Griffin MT, Figueroa KW, Liller S and Ehlert FJ. (2007) Estimation of agonist activity at G protein-coupled receptors: analysis of M2 muscarinic receptor signaling through Gi/o,Gs, and G15. J Pharmacol Exp Ther 321: 1193-207 [PMID:17392404]

118. Grillner P, Bonci A, Svensson TH, Bernardi G and Mercuri NB. (1999) Presynaptic muscarinic (M3) receptors reduce excitatory transmission in dopamine neurons of the rat mesencephalon. Neuroscience 91: 557-65 [PMID:10366013]

119. Guo FF, Kumahara E and Saffen D. (2001) A CalDAG-GEFI/Rap1/B-Raf cassette couples M(1) muscarinic acetylcholine receptors to the activation of ERK1/2. J Biol Chem 276: 25568-81 [PMID:11292831]

120. Haberberger R, Schultheiss G and Diener M. (2006) Epithelial muscarinic M1 receptors contribute to carbachol-induced ion secretion in mouse colon. Eur J Pharmacol 530: 229-233 [PMID:16405887]

121. Haga K, Kruse AC, Asada H, Yurugi-Kobayashi T, Shiroishi M, Zhang C, Weis WI, Okada T, Kobilka BK and Haga T et al.. (2012) Structure of the human M2 muscarinic acetylcholine receptor bound to an antagonist. Nature 482: 547-51 [PMID:22278061]

122. Hagan JJ, Tonnaer JA and Broekkamp CL. (1987) Cholinergic stimulation of drinking from the lateral hypothalamus: indications for M2 muscarinic receptor mediation. Pharmacol Biochem Behav 26: 771-9 [PMID:3602034]

123. Hamilton SE, Hardouin SN, Anagnostaras SG, Murphy GG, Richmond KN, Silva AJ, Feigl EO and Nathanson NM. (2001) Alteration of cardiovascular and neuronal function in M1 knockout mice. Life Sci 68: 2489-93 [PMID:11392617]

124. Hamilton SE, Loose MD, Qi M, Levey AI, Hille B, McKnight GS, Idzerda RL and Nathanson NM. (1997) Disruption of the $\mathrm{m} 1$ receptor gene ablates muscarinic receptor-dependent $\mathrm{M}$ current regulation and seizure activity in mice. Proc Natl Acad Sci USA 94: 13311-6 [PMID:9371842] 
125. Hammer R, Berrie CP, Birdsall NJ, Burgen AS and Hulme EC. (1980) Pirenzepine distinguishes between different subclasses of muscarinic receptors. Nature 283: 90-2 [PMID:7350532]

126. Harvey AL, Kornisiuk E, Bradley KN, Cerveñansky C, Durán R, Adrover M, Sánchez G and Jerusalinsky D. (2002) Effects of muscarinic toxins MT1 and MT2 from green mamba on different muscarinic cholinoceptors. Neurochem Res 27: 1543-54 [PMID:12512959]

127. Hassall CJ, Stanford SC, Burnstock G and Buckley NJ. (1993) Co-expression of four muscarinic receptor genes by the intrinsic neurons of the rat and guinea-pig heart. Neuroscience 56: 10418 [PMID:8284034]

128. Hegde SS. (2006) Muscarinic receptors in the bladder: from basic research to therapeutics. $\mathrm{Br} \mathrm{J}$ Pharmacol 147 Suppl 2: S80-7 [PMID:16465186]

129. Hegde SS, Choppin A, Bonhaus D, Briaud S, Loeb M, Moy TM, Loury D and Eglen RM. (1997) Functional role of M2 and M3 muscarinic receptors in the urinary bladder of rats in vitro and in vivo. Br J Pharmacol 120: 1409-18 [PMID:9113359]

130. Hegde SS, Pulido-Rios MT, Luttmann MA, Foley JJ, Hunsberger GE, Steinfeld T, Lee T, Ji Y, Mammen MM and Jasper JR. (2018) Pharmacological properties of revefenacin (TD-4208), a novel, nebulized long-acting, and lung selective muscarinic antagonist, at human recombinant muscarinic receptors and in rat, guinea pig, and human isolated airway tissues. Pharmacol Res Perspect 6: e00400 [PMID:29736245]

131. Hern JA, Baig AH, Mashanov GI, Birdsall B, Corrie JE, Lazareno S, Molloy JE and Birdsall NJ. (2010) Formation and dissociation of M1 muscarinic receptor dimers seen by total internal reflection fluorescence imaging of single molecules. Proc Natl Acad Sci USA 107: 2693-8 [PMID:20133736]

132. Hill JJ and Peralta EG. (2001) Inhibition of a Gi-activated potassium channel (GIRK1/4) by the Gq-coupled $\mathrm{m} 1$ muscarinic acetylcholine receptor. J Biol Chem 276: 5505-10 [PMID:11060307]

133. Hirose H, Aoki I, Kimura T, Fujikawa T, Numazawa T, Sasaki K, Sato A, Hasegawa T, Nishikibe $\mathrm{M}$ and Mitsuya $\mathrm{M}$ et al.. (2001) Pharmacological properties of (2R)-N-[1-(6-aminopyridin-2ylmethyl)piperidin-4-yl]-2-[(1R)-3,3-difluorocyclopentyl]-2-hydroxy-2-phenylacetamide: a novel mucarinic antagonist with M(2)-sparing antagonistic activity. J Pharmacol Exp Ther 297: 790-7 [PMID:11303071]

134. Hohmann CF, Potter ED and Levey AI. (1995) Development of muscarinic receptor subtypes in the forebrain of the mouse. J Comp Neurol 358: 88-101 [PMID:7560279]

135. Hu Y, Rajan L and Schilling WP. (1994) Ca2+ signaling in Sf9 insect cells and the functional expression of a rat brain M5 muscarinic receptor. Am J Physiol 266: C1736-43 [PMID:8023903]

136. Huang F, Buchwald P, Browne CE, Farag HH, Wu WM, Ji F, Hochhaus G and Bodor N. (2001) Receptor binding studies of soft anticholinergic agents. AAPS PharmSci 3: E30 [PMID:12049493]

137. Ikeda K, Kobayashi S, Suzuki M, Miyata K, Takeuchi M, Yamada T and Honda K. (2002) M(3) receptor antagonism by the novel antimuscarinic agent solifenacin in the urinary bladder and salivary gland. Naunyn Schmiedebergs Arch Pharmacol 366: 97-103 [PMID:12122494]

138. Ilien B, Glasser N, Clamme JP, Didier P, Piemont E, Chinnappan R, Daval SB, Galzi JL and Mely Y. (2009) Pirenzepine promotes the dimerization of muscarinic M1 receptors through a threestep binding process. J Biol Chem 284: 19533-43 [PMID:19451648]

139. Imeri L, Bianchi S, Angeli P and Mancia M. (1991) Differential effects of M2 and M3 muscarinic antagonists on the sleep-wake cycle. Neuroreport 2: 383-5 [PMID:1912471]

140. Imeri L, Bianchi S, Angeli P and Mancia M. (1994) Selective blockade of different brain stem muscarinic receptor subtypes: effects on the sleep-wake cycle. Brain Res 636: 68-72 [PMID:8156412]

141. Imeri L, Bianchi S, Angeli P and Mancia M. (1996) Muscarinic receptor subtypes in the medial preoptic area and sleep-wake cycles. Neuroreport 7: 417-20 [PMID:8730795]

142. Jagoda EM, Kiesewetter DO, Shimoji K, Ravasi L, Yamada M, Gomeza J, Wess J and Eckelman WC. (2003) Regional brain uptake of the muscarinic ligand, [18F]FP-TZTP, is greatly decreased in M2 receptor knockout mice but not in M1, M3 and M4 receptor knockout mice. Neuropharmacology 44: 653-61 [PMID:12668051]

143. Jakubík J, Bacáková L, el-Fakahany EE and Tucek S. (1995) Subtype selectivity of the positive allosteric action of alcuronium at cloned M1-M5 muscarinic acetylcholine receptors. $J$ Pharmacol Exp Ther 274: 1077-83 [PMID:7562472]

144. Jakubík J, Bacáková L, El-Fakahany EE and Tucek S. (1997) Positive cooperativity of acetylcholine and other agonists with allosteric ligands on muscarinic acetylcholine receptors. Mol Pharmacol 52: 172-9 [PMID:9224827]

145. Jakubík J, El-Fakahany EE and Dolezal V. (2006) Differences in kinetics of xanomeline binding and selectivity of activation of $\mathrm{G}$ proteins at $\mathrm{M}(1)$ and $\mathrm{M}(2)$ muscarinic acetylcholine receptors. Mol Pharmacol 70: 656-66 [PMID:16675658]

146. Jeon WJ, Gibbons AS and Dean B. (2013) The use of a modified [3H]4-DAMP radioligand binding assay with increased selectivity for muscarinic M3 receptor shows that cortical CHRM3 levels are not altered in mood disorders. Prog Neuropsychopharmacol Biol Psychiatry 47: 7-12 
[PMID:23962466]

147. Jolkkonen M, van Giersbergen PL, Hellman U, Wernstedt C and Karlsson E. (1994) A toxin from the green mamba Dendroaspis angusticeps: amino acid sequence and selectivity for muscarinic m4 receptors. FEBS Lett 352: 91-4 [PMID:7925952]

148. Jones CK, Brady AE, Davis AA, Xiang Z, Bubser M, Tantawy MN, Kane AS, Bridges TM, Kennedy JP and Bradley SR et al.. (2008) Novel selective allosteric activator of the M1 muscarinic acetylcholine receptor regulates amyloid processing and produces antipsychotic-like activity in rats. J Neurosci 28: 10422-33 [PMID:18842902]

149. Karasawa H, Taketo MM and Matsui M. (2003) Loss of anti-cataleptic effect of scopolamine in mice lacking muscarinic acetylcholine receptor subtype 4. Eur J Pharmacol 468: 15-9 [PMID:12729838]

150. Kashihara K, Varga EV, Waite SL, Roeske WR and Yamamura HI. (1992) Cloning of the rat M3, M4 and M5 muscarinic acetylcholine receptor genes by the polymerase chain reaction (PCR) and the pharmacological characterization of the expressed genes. Life Sci 51: 955-71 [PMID:1325587]

151. Keov P, López L, Devine SM, Valant C, Lane JR, Scammells PJ, Sexton PM and Christopoulos A. (2014) Molecular mechanisms of bitopic ligand engagement with the M1 muscarinic acetylcholine receptor. J Biol Chem 289: 23817-37 [PMID:25006252]

152. Keov P, Valant C, Devine SM, Lane JR, Scammells PJ, Sexton PM and Christopoulos A. (2013) Reverse engineering of the selective agonist TBPB unveils both orthosteric and allosteric modes of action at the $\mathrm{M}_{1}$ muscarinic acetylcholine receptor. Mol Pharmacol 84: 425-37 [PMID:23798605]

153. Khattar SK, Bora RS, Priyadarsiny P, Gupta D, Khanna A, Narayanan KL, Babu V, Chugh A and Saini KS. (2006) High level stable expression of pharmacologically active human M1-M5 muscarinic receptor subtypes in mammalian cells. Biotechnol Lett 28: 121-9 [PMID:16369696]

154. Khurana S, Yamada M, Wess J, Kennedy RH and Raufman JP. (2005) Deoxycholyltaurine-induced vasodilation of rodent aorta is nitric oxide- and muscarinic M(3) receptor-dependent. Eur J Pharmacol 517: 103-10 [PMID:15964566]

155. Kiesewetter DO, Carson RE, Jagoda EM, Endres CJ, Der MG, Herscovitch P and Eckelman WC. (1997) In vivo muscarinic binding selectivity of $(\mathrm{R}, \mathrm{S})-$ and $(\mathrm{R}, \mathrm{R})-[18 \mathrm{~F}]-$ fluoromethyl QNB. Bioorg Med Chem 5: 1555-67 [PMID:9313861]

156. Kim JY, Yang MS, Oh CD, Kim KT, Ha MJ, Kang SS and Chun JS. (1999) Signalling pathway leading to an activation of mitogen-activated protein kinase by stimulating M3 muscarinic receptor. Biochem J 337 ( Pt 2): 275-80 [PMID:9882625]

157. Klett CP, Zimonjic DB, Keck CL and Bonner TI. (1998) Localization of the rat M1 muscarinic receptor gene to chromosome 1q43-51. Mamm Genome 9: 476-8 [PMID:9585439]

158. Kono M, Nakamura Y, Ishiura Y, Komatsu K, Kontani H and Namiki M. (2006) Central muscarinic receptor subtypes regulating voiding in rats. J Urol 175: 353-7 [PMID:16406941]

159. Kovacs I, Yamamura HI, Waite SL, Varga EV and Roeske WR. (1998) Pharmacological comparison of the cloned human and rat M2 muscarinic receptor genes expressed in the murine fibroblast (B82) cell line. J Pharmacol Exp Ther 284: 500-7 [PMID:9454790]

160. Kruse AC, Hu J, Pan AC, Arlow DH, Rosenbaum DM, Rosemond E, Green HF, Liu T, Chae PS and Dror RO et al.. (2012) Structure and dynamics of the M3 muscarinic acetylcholine receptor. Nature 482: 552-6 [PMID:22358844]

161. Kruse AC, Ring AM, Manglik A, Hu J, Hu K, Eitel K, Hübner H, Pardon E, Valant C and Sexton PM et al.. (2013) Activation and allosteric modulation of a muscarinic acetylcholine receptor. Nature 504: 101-6 [PMID:24256733]

162. Lachowicz JE, Lowe D, Duffy RA, Ruperto V, Taylor LA, Guzik H, Brown J, Berger JG, Tice M and McQuade R et al.. (1999) SCH 57790: a novel M2 receptor selective antagonist. Life Sci 64: 535-9 [PMID:10069520]

163. Lainé DI, McCleland B, Thomas S, Neipp C, Underwood B, Dufour J, Widdowson KL, Palovich MR, Blaney FE and Foley JJ et al.. (2009) Discovery of novel 1-azoniabicyclo[2.2.2]octane muscarinic acetylcholine receptor antagonists. J Med Chem 52: 2493-505 [PMID:19317446]

164. Lambrecht G, Moser U, Grimm U, Pfaff O, Hermanni U, Hildebrandt C, Waelbroeck M, Christophe J and Mutschler E. (1993) New functionally selective muscarinic agonists. Life Sci 52: 481-8 [PMID:7680092]

165. Lammers JW, Minette P, McCusker M and Barnes PJ. (1989) The role of pirenzepine-sensitive (M1) muscarinic receptors in vagally mediated bronchoconstriction in humans. Am Rev Respir Dis 139: 446-9 [PMID:2521552]

166. Lamping KG, Wess J, Cui Y, Nuno DW and Faraci FM. (2004) Muscarinic (M) receptors in coronary circulation: gene-targeted mice define the role of M2 and M3 receptors in response to acetylcholine. Arterioscler Thromb Vasc Biol 24: 1253-1258 [PMID:15130910]

167. Langmead CJ, Austin NE, Branch CL, Brown JT, Buchanan KA, Davies CH, Forbes IT, Fry VA, Hagan JJ and Herdon HJ et al.. (2008) Characterization of a CNS penetrant, selective M1 muscarinic receptor agonist, 77-LH-28-1. Br J Pharmacol 154: 1104-15 [PMID:18454168] 
168. Langmead CJ, Fry VA, Forbes IT, Branch CL, Christopoulos A, Wood MD and Herdon HJ. (2006) Probing the molecular mechanism of interaction between 4-n-butyl-1-[4-(2-methylphenyl)-4-oxo1-butyl]-piperidine (AC-42) and the muscarinic $\mathrm{M}(1)$ receptor: direct pharmacological evidence that AC-42 is an allosteric agonist. Mol Pharmacol 69: 236-46 [PMID:16207821]

169. Lazareno S and Birdsall NJ. (1995) Detection, quantitation, and verification of allosteric interactions of agents with labeled and unlabeled ligands at $\mathrm{G}$ protein-coupled receptors: interactions of strychnine and acetylcholine at muscarinic receptors. Mol Pharmacol 48: $362-78$ [PMID:7651370]

170. Lazareno S and Birdsall NJ. (1993) Pharmacological characterization of acetylcholine-stimulated [35S]-GTP gamma S binding mediated by human muscarinic m1-m4 receptors: antagonist studies. Br J Pharmacol 109: 1120-7 [PMID:8401923]

171. Lazareno S, Dolezal V, Popham A and Birdsall NJ. (2004) Thiochrome enhances acetylcholine affinity at muscarinic M4 receptors: receptor subtype selectivity via cooperativity rather than affinity. Mol Pharmacol 65: 257-66 [PMID:14722259]

172. Lazareno S, Farries T and Birdsall NJ. (1993) Pharmacological characterization of guanine nucleotide exchange reactions in membranes from CHO cells stably transfected with human muscarinic receptors m1-m4. Life Sci 52: 449-56 [PMID:8441327]

173. Lazareno S, Gharagozloo P, Kuonen D, Popham A and Birdsall NJ. (1998) Subtype-selective positive cooperative interactions between brucine analogues and acetylcholine at muscarinic receptors: radioligand binding studies. Mol Pharmacol 53: 573-89 [PMID:9495826]

174. Lazareno S, Popham A and Birdsall NJ. (2000) Allosteric interactions of staurosporine and other indolocarbazoles with $\mathrm{N}$-[methyl-(3)H]scopolamine and acetylcholine at muscarinic receptor subtypes: identification of a second allosteric site. Mol Pharmacol 58: 194-207 [PMID:10860942]

175. Lazareno S, Popham A and Birdsall NJ. (2002) Analogs of WIN 62,577 define a second allosteric site on muscarinic receptors. Mol Pharmacol 62: 1492-505 [PMID:12435818]

176. Leach K, Davey AE, Felder CC, Sexton PM and Christopoulos A. (2011) The role of transmembrane domain 3 in the actions of orthosteric, allosteric, and atypical agonists of the M4 muscarinic acetylcholine receptor. Mol Pharmacol 79: 855-65 [PMID:21300722]

177. Leach K, Loiacono RE, Felder CC, McKinzie DL, Mogg A, Shaw DB, Sexton PM and Christopoulos A. (2010) Molecular mechanisms of action and in vivo validation of an M4 muscarinic acetylcholine receptor allosteric modulator with potential antipsychotic properties. Neuropsychopharmacology 35: 855-69 [PMID:19940843]

178. Levey AI, Edmunds SM, Heilman CJ, Desmond TJ and Frey KA. (1994) Localization of muscarinic $\mathrm{m} 3$ receptor protein and $\mathrm{M} 3$ receptor binding in rat brain. Neuroscience 63: 207-21 [PMID:7898649]

179. Levey AI, Edmunds SM, Koliatsos V, Wiley RG and Heilman CJ. (1995) Expression of m1-m4 muscarinic acetylcholine receptor proteins in rat hippocampus and regulation by cholinergic innervation. J Neurosci 15: 4077-92 [PMID:7751967]

180. Liao CF, Schilling WP, Birnbaumer M and Birnbaumer L. (1990) Cellular responses to stimulation of the M5 muscarinic acetylcholine receptor as seen in murine L cells. J Biol Chem 265: 11273-84 [PMID:2162842]

181. Liao CF, Themmen AP, Joho R, Barberis C, Birnbaumer M and Birnbaumer L. (1989) Molecular cloning and expression of a fifth muscarinic acetylcholine receptor. J Biol Chem 264: 7328-37 [PMID:2540186]

182. Lin S, Kajimura M, Takeuchi K, Kodaira M, Hanai H and Kaneko E. (1997) Expression of muscarinic receptor subtypes in rat gastric smooth muscle: effect of M3 selective antagonist on gastric motility and emptying. Dig Dis Sci 42: 907-14 [PMID:9149041]

183. Loudon JM, Bromidge SM, Brown F, Clark MS, Hatcher JP, Hawkins J, Riley GJ, Noy G and Orlek BS. (1997) SB 202026: a novel muscarinic partial agonist with functional selectivity for M1 receptors. J Pharmacol Exp Ther 283: 1059-68 [PMID:9399977]

184. Lucas JL, DeYoung JA and Sadee W. (2001) Single nucleotide polymorphisms of the human M1 muscarinic acetylcholine receptor gene. AAPS PharmSci 3: E31 [PMID:12049494]

185. Ma L, Seager MA, Seager M, Wittmann M, Jacobson M, Bickel D, Burno M, Jones K, Graufelds VK and Xu G et al.. (2009) Selective activation of the M1 muscarinic acetylcholine receptor achieved by allosteric potentiation. Proc Natl Acad Sci USA 106: 15950-5 [PMID:19717450]

186. Maeda S, Qu Q, Robertson MJ, Skiniotis G and Kobilka BK. (2019) Structures of the M1 and M2 muscarinic acetylcholine receptor/G-protein complexes. Science 364: 552-557 [PMID:31073061]

187. Maeda S, Xu J, N Kadji FM, Clark MJ, Zhao J, Tsutsumi N, Aoki J, Sunahara RK, Inoue A and Garcia KC et al.. (2020) Structure and selectivity engineering of the $\mathrm{M}_{1}$ muscarinic receptor toxin complex. Science 369: 161-167 [PMID:32646996]

188. Maggio R, Barbier P, Bolognesi ML, Minarini A, Tedeschi D and Melchiorre C. (1994) Binding profile of the selective muscarinic receptor antagonist tripitramine. Eur J Pharmacol 268: 459462 [PMID:7805774]

189. Mak JC and Barnes PJ. (1989) Muscarinic receptor subtypes in human and guinea pig lung. Eur J 
Pharmacol 164: 223-30 [PMID:2759174]

190. Mandai T, Sako Y, Kurimoto E, Shimizu Y, Nakamura M, Fushimi M, Maeda R, Miyamoto M and Kimura H. (2020) T-495, a novel low cooperative $\mathrm{M}_{1}$ receptor positive allosteric modulator, improves memory deficits associated with cholinergic dysfunction and is characterized by low gastrointestinal side effect risk. Pharmacol Res Perspect 8: e00560 [PMID:31990455]

191. Marino MJ, Rouse ST, Levey AI, Potter LT and Conn PJ. (1998) Activation of the genetically defined $\mathrm{m} 1$ muscarinic receptor potentiates N-methyl-D-aspartate (NMDA) receptor currents in hippocampal pyramidal cells. Proc Natl Acad Sci USA 95: 11465-70 [PMID:9736760]

192. Marlo JE, Niswender CM, Days EL, Bridges TM, Xiang Y, Rodriguez AL, Shirey JK, Brady AE, Nalywajko T and Luo Q et al.. (2009) Discovery and characterization of novel allosteric potentiators of M1 muscarinic receptors reveals multiple modes of activity. Mol Pharmacol 75: 577-88 [PMID:19047481]

193. Matsui M, Araki Y, Karasawa H, Matsubara N, Taketo MM and Seldin MF. (1999) Mapping of five subtype genes for muscarinic acetylcholine receptor to mouse chromosomes. Genes Genet Syst 74: 15-21 [PMID:10549128]

194. Matsui M, Griffin MT, Shehnaz D, Taketo MM and Ehlert FJ. (2003) Increased relaxant action of forskolin and isoproterenol against muscarinic agonist-induced contractions in smooth muscle from M2 receptor knockout mice. J Pharmacol Exp Ther 305: 106-13 [PMID:12649358]

195. Matsui M, Motomura D, Karasawa H, Fujikawa T, Jiang J, Komiya Y, Takahashi S and Taketo MM. (2000) Multiple functional defects in peripheral autonomic organs in mice lacking muscarinic acetylcholine receptor gene for the M3 subtype. Proc Natl Acad Sci USA 97: 9579-84 [PMID:10944224]

196. Matsui M, Yamada S, Oki T, Manabe T, Taketo MM and Ehlert FJ. (2004) Functional analysis of muscarinic acetylcholine receptors using knockout mice. Life Sci 75: 2971-81 [PMID:15474550]

197. May LT, Avlani VA, Langmead CJ, Herdon HJ, Wood MD, Sexton PM and Christopoulos A. (2007) Structure-function studies of allosteric agonism at M2 muscarinic acetylcholine receptors. $\mathrm{Mol}$ Pharmacol 72: 463-76 [PMID:17525129]

198. May LT, Leach K, Sexton PM and Christopoulos A. (2007) Allosteric modulation of G proteincoupled receptors. Annu Rev Pharmacol Toxicol 47: 1-51 [PMID:17009927]

199. McCormack DG, Mak JC, Minette P and Barnes PJ. (1988) Muscarinic receptor subtypes mediating vasodilation in the pulmonary artery. Eur J Pharmacol 158: 293-7 [PMID:3253104]

200. Mei L, Lai J, Roeske WR, Fraser CM, Venter JC and Yamamura HI. (1989) Pharmacological characterization of the M1 muscarinic receptors expressed in murine fibroblast B82 cells. $J$ Pharmacol Exp Ther 248: 661-70 [PMID:2537406]

201. Messer Jr WS, Bohnett M and Stibbe J. (1990) Evidence for a preferential involvement of M1 muscarinic receptors in representational memory. Neurosci Lett 116: 184-9 [PMID:2259447]

202. Messer WS. (2002) Cholinergic agonists and the treatment of Alzheimer's disease. Curr Top Med Chem 2: 353-358 [PMID:11966459]

203. Michal P, El-Fakahany EE and Dolezal V. (2007) Muscarinic M2 receptors directly activate Gq/11 and Gs G-proteins. J Pharmacol Exp Ther 320: 607-14 [PMID:17065363]

204. Migeon JC, Thomas SL and Nathanson NM. (1995) Differential coupling of $\mathrm{m} 2$ and $\mathrm{m} 4$ muscarinic receptors to inhibition of adenylyl cyclase by Gi alpha and G(o)alpha subunits. J Biol Chem 270: 16070-4 [PMID:7608168]

205. Miller AD and Blaha CD. (2005) Midbrain muscarinic receptor mechanisms underlying regulation of mesoaccumbens and nigrostriatal dopaminergic transmission in the rat. Eur J Neurosci 21: 1837-46 [PMID:15869479]

206. Miller JH, Aagaard PJ, Gibson VA and McKinney M. (1992) Binding and functional selectivity of himbacine for cloned and neuronal muscarinic receptors. J Pharmacol Exp Ther 263: 663-7 [PMID:1331410]

207. Miller JH, Gibson VA and McKinney M. (1991) Binding of [3H]AF-DX 384 to cloned and native muscarinic receptors. J Pharmacol Exp Ther 259: 601-7 [PMID:1941609]

208. Minarini A, Marucci G, Bellucci C, Giorgi G, Tumiatti V, Bolognesi ML, Matera R, Rosini M and Melchiorre C. (2008) Design, synthesis, and biological evaluation of pirenzepine analogs bearing a 1,2-cyclohexanediamine and perhydroquinoxaline units in exchange for the piperazine ring as antimuscarinics. Bioorg Med Chem 16: 7311-20 [PMID:18595721]

209. Minette PA and Barnes PJ. (1988) Prejunctional inhibitory muscarinic receptors on cholinergic nerves in human and guinea pig airways. J Appl Physiol 64: 2532-7 [PMID:3403437]

210. Miyakawa T, Yamada M, Duttaroy A and Wess J. (2001) Hyperactivity and intact hippocampusdependent learning in mice lacking the M1 muscarinic acetylcholine receptor. J Neurosci $\mathbf{2 1}$ : 5239-50 [PMID:11438599]

211. Mohr M, Heller E, Ataie A, Mohr K and Holzgrabe U. (2004) Development of a new type of allosteric modulator of muscarinic receptors: hybrids of the antagonist AF-DX 384 and the hexamethonio derivative W84. J Med Chem 47: 3324-7 [PMID:15163212]

212. Moo EV, Sexton PM, Christopoulos A and Valant C. (2018) Utility of an "Allosteric SiteImpaired" $\mathrm{M}_{2}$ Muscarinic Acetylcholine Receptor as a Novel Construct for Validating 
Mechanisms of Action of Synthetic and Putative Endogenous Allosteric Modulators. Mol Pharmacol 94: 1298-1309 [PMID:30213802]

213. Moriya H, Takagi Y, Nakanishi T, Hayashi M, Tani T and Hirotsu I. (1999) Affinity profiles of various muscarinic antagonists for cloned human muscarinic acetylcholine receptor (mAChR) subtypes and mAChRs in rat heart and submandibular gland. Life Sci 64: 2351-8 [PMID:10374898]

214. MRC. M1 muscarinic receptor agonist.

215. Naito R, Yonetoku Y, Okamoto Y, Toyoshima A, Ikeda K and Takeuchi M. (2005) Synthesis and antimuscarinic properties of quinuclidin-3-yl 1,2,3,4-tetrahydroisoquinoline-2-carboxylate derivatives as novel muscarinic receptor antagonists. J Med Chem 48: 6597-606 [PMID:16220976]

216. Nakamura T, Matsui M, Uchida K, Futatsugi A, Kusakawa S, Matsumoto N, Nakamura K, Manabe T, Taketo MM and Mikoshiba K. (2004) M(3) muscarinic acetylcholine receptor plays a critical role in parasympathetic control of salivation in mice. J Physiol (Lond.) 558: 561-75 [PMID:15146045]

217. Narducci F, Bassotti G, Daniotti S, Del Soldato P, Pelli MA and Morelli A. (1985) Identification of muscarinic receptor subtype mediating colonic response to eating. Dig Dis Sci 30: 124-8 [PMID:3838152]

218. Nathanson NM. (2000) A multiplicity of muscarinic mechanisms: enough signaling pathways to take your breath away. Proc Natl Acad Sci USA 97: 6245-7 [PMID:10841527]

219. Nawaratne V, Leach K, Felder CC, Sexton PM and Christopoulos A. (2010) Structural determinants of allosteric agonism and modulation at the M4 muscarinic acetylcholine receptor: identification of ligand-specific and global activation mechanisms. J Biol Chem 285: 19012-21 [PMID:20406819]

220. Nawaratne V, Leach K, Suratman N, Loiacono RE, Felder CC, Armbruster BN, Roth BL, Sexton PM and Christopoulos A. (2008) New insights into the function of M4 muscarinic acetylcholine receptors gained using a novel allosteric modulator and a DREADD (designer receptor exclusively activated by a designer drug). Mol Pharmacol 74: 1119-31 [PMID:18628403]

221. Nelson CP, Nahorski SR and Challiss RA. (2006) Constitutive activity and inverse agonism at the M2 muscarinic acetylcholine receptor. J Pharmacol Exp Ther 316: 279-88 [PMID:16188951]

222. Nenasheva TA, Neary M, Mashanov GI, Birdsall NJ, Breckenridge RA and Molloy JE. (2013) Abundance, distribution, mobility and oligomeric state of $\mathrm{M}_{2}$ muscarinic acetylcholine receptors in live cardiac muscle. J Mol Cell Cardiol 57: 129-36 [PMID:23357106]

223. Newman AH, Kline RH, Allen AC, Izenwasser S, George C and Katz JL. (1995) Novel 4'substituted and 4',4"-disubstituted 3 alpha-(diphenylmethoxy)tropane analogs as potent and selective dopamine uptake inhibitors. J Med Chem 38: 3933-40 [PMID:7562926]

224. Näsman J, Jolkkonen M, Ammoun S, Karlsson E and Akerman KE. (2000) Recombinant expression of a selective blocker of M(1) muscarinic receptors. Biochem Biophys Res Commun 271: 435-9 [PMID:10799315]

225. Oki T, Takagi Y, Inagaki S, Taketo MM, Manabe T, Matsui M and Yamada S. (2005) Quantitative analysis of binding parameters of [3H]N-methylscopolamine in central nervous system of muscarinic acetylcholine receptor knockout mice. Brain Res Mol Brain Res 133: 6-11 [PMID:15661360]

226. Olianas MC, Adem A, Karlsson E and Onali P. (1996) Rat striatal muscarinic receptors coupled to the inhibition of adenylyl cyclase activity: potent block by the selective $\mathrm{m} 4$ ligand muscarinic toxin 3 (MT3). Br J Pharmacol 118: 283-8 [PMID:8735628]

227. Olianas MC, Ingianni A, Maullu C, Adem A, Karlsson E and Onali P. (1999) Selectivity profile of muscarinic toxin 3 in functional assays of cloned and native receptors. $J$ Pharmacol Exp Ther 288: 164-70 [PMID:9862767]

228. Olianas MC, Maullu C, Adem A, Mulugeta E, Karlsson E and Onali P. (2000) Inhibition of acetylcholine muscarinic $\mathrm{M}(1)$ receptor function by the $\mathrm{M}(1)$-selective ligand muscarinic toxin 7 (MT-7). Br J Pharmacol 131: 447-52 [PMID:11015294]

229. Olianas MC and Onali P. (1999) PD 102807, a novel muscarinic M4 receptor antagonist, discriminates between striatal and cortical muscarinic receptors coupled to cyclic AMP. Life Sci 65: 2233-40 [PMID:10576595]

230. Onali P and Olianas MC. (2002) Muscarinic M4 receptor inhibition of dopamine D1-like receptor signalling in rat nucleus accumbens. Eur J Pharmacol 448: 105-11 [PMID:12144929]

231. Orman B, Sterin-Borda L, Reina S and Borda ES. (2005) Neuronal nitric oxide synthase activity in rat urinary bladder detrusor: participation in M3 and M4 muscarinic receptor function. Auton Autacoid Pharmacol 25: 93-100 [PMID:15955028]

232. Ozenil M, Pacher K, Balber T, Vraka C, Roller A, Holzer W, Spreitzer H, Mitterhauser M, Wadsak W and Hacker M et al.. (2020) Enhanced arecoline derivatives as muscarinic acetylcholine receptor M1 ligands for potential application as PET radiotracers. Eur J Med Chem 204: 112623 [PMID:32717485]

233. Pazos A, Wiederhold KH and Palacios JM. (1986) Central pressor effects induced by muscarinic 
receptor agonists: evidence for a predominant role of the M2 receptor subtype. Eur J Pharmacol 125: 63-70 [PMID:3732392]

234. Pei XF, Gupta TH, Badio B, Padgett WL and Daly JW. (1998) 6beta-Acetoxynortropane: a potent muscarinic agonist with apparent selectivity toward M2-receptors. J Med Chem 41: 2047-55 [PMID:9622546]

235. Pepitoni S, Wood IC and Buckley NJ. (1997) Structure of the $\mathrm{m} 1 \mathrm{muscarinic}$ acetylcholine receptor gene and its promoter. J Biol Chem 272: 17112-7 [PMID:9202029]

236. Peralta EG, Ashkenazi A, Winslow JW, Ramachandran J and Capon DJ. (1988) Differential regulation of PI hydrolysis and adenylyl cyclase by muscarinic receptor subtypes. Nature 334: 434-7 [PMID:2841607]

237. Peralta EG, Ashkenazi A, Winslow JW, Smith DH, Ramachandran J and Capon DJ. (1987) Distinct primary structures, ligand-binding properties and tissue-specific expression of four human muscarinic acetylcholine receptors. EMBO J 6: 3923-9 [PMID:3443095]

238. Pfeiffer A, Rochlitz H, Noelke B, Tacke R, Moser U, Mutschler E and Lambrecht G. (1990) Muscarinic receptors mediating acid secretion in isolated rat gastric parietal cells are of M3 type. Gastroenterology 98: 218-22 [PMID:2293581]

239. Polidori C, Massi M, Lambrecht G, Mutschler E, Tacke R and Melchiorre C. (1990) Selective antagonists provide evidence that M1 muscarinic receptors may mediate carbachol-induced drinking in the rat. Eur J Pharmacol 179: 159-65 [PMID:2364977]

240. Post MJ, Te Biesebeek JD, Doods HN, Wemer J, Van Rooji HH and Porsius AJ. (1991) Functional characterization of the muscarinic receptor in rat lungs. Eur J Pharmacol 202: 67-72 [PMID:1723953]

241. Prat M, Buil MA, Fernández MD, Castro J, Monleón JM, Tort L, Casals G, Ferrer M, Huerta JM and Espinosa S et al.. (2011) Discovery of novel quaternary ammonium derivatives of (3R)quinuclidinyl carbamates as potent and long acting muscarinic antagonists. Bioorg Med Chem Lett 21: 3457-61 [PMID:21524581]

242. Prat M, Fernández D, Buil MA, Crespo MI, Casals G, Ferrer M, Tort L, Castro J, Monleón JM and Gavaldà A et al.. (2009) Discovery of novel quaternary ammonium derivatives of (3R)quinuclidinol esters as potent and long-acting muscarinic antagonists with potential for minimal systemic exposure after inhaled administration: identification of (3R)-3-\{[hydroxy(di-2thienyl)acetyl]oxy\}-1-(3-phenoxypropyl)-1-azoniabicyclo[2.2.2]octane bromide (aclidinium bromide). J Med Chem 52: 5076-92 [PMID:19653626]

243. Preiksaitis HG, Krysiak PS, Chrones T, Rajgopal V and Laurier LG. (2000) Pharmacological and molecular characterization of muscarinic receptor subtypes in human esophageal smooth muscle. J Pharmacol Exp Ther 295: 879-88 [PMID:11082420]

244. Pönicke K, Heinroth-Hoffmann I and Brodde OE. (2003) Demonstration of functional M3muscarinic receptors in ventricular cardiomyocytes of adult rats. Br J Pharmacol 138: 156-60 [PMID:12522085]

245. Renuka TR, Robinson R and Paulose CS. (2006) Increased insulin secretion by muscarinic M1 and M3 receptor function from rat pancreatic islets in vitro. Neurochem Res 31: 313-20 [PMID:16733808]

246. Rhodes ME, Billings TE, Czambel RK and Rubin RT. (2005) Pituitary-adrenal responses to cholinergic stimulation and acute mild stress are differentially elevated in male and female $\mathrm{M}(2)$ muscarinic receptor knockout mice. J Neuroendocrinol 17: 817-26 [PMID:16280029]

247. Richards MH and van Giersbergen PL. (1995) Human muscarinic receptors expressed in A9L and CHO cells: activation by full and partial agonists. Br J Pharmacol 114: 1241-9 [PMID:7620715]

248. Rosenblum K, Futter M, Jones M, Hulme EC and Bliss TV. (2000) ERKI/II regulation by the muscarinic acetylcholine receptors in neurons. J Neurosci 20: 977-85 [PMID:10648702]

249. Ross EM and Berstein G. (1993) Regulation of the M1 muscarinic receptor-Gq-phospholipase Cbeta pathway by nucleotide exchange and GTP hydrolysis. Life Sci 52: 413-9 [PMID:8441322]

250. Salmon M, Luttmann MA, Foley JJ, Buckley PT, Schmidt DB, Burman M, Webb EF, DeHaas CJ, Kotzer CJ and Barrett VJ et al.. (2013) Pharmacological characterization of GSK573719 (umeclidinium): a novel, long-acting, inhaled antagonist of the muscarinic cholinergic receptors for treatment of pulmonary diseases. J Pharmacol Exp Ther 345: 260-70 [PMID:23435542]

251. Sams AG, Hentzer M, Mikkelsen GK, Larsen K, Bundgaard C, Plath N, Christoffersen CT and Bang-Andersen B. (2010) Discovery of N-\{1-[3-(3-oxo-2,3-dihydrobenzo[1,4]oxazin-4yl)propyl]piperidin-4-yl\}-2-phenylacetamide (Lu AE51090): an allosteric muscarinic M1 receptor agonist with unprecedented selectivity and procognitive potential. J Med Chem 53: 6386-97 [PMID:20684563]

252. Sandvik AK, Kleveland PM and Waldum HL. (1988) Muscarinic M2 stimulation releases histamine in the totally isolated, vascularly perfused rat stomach. Scand J Gastroenterol 23: 1049-56 [PMID:2470130]

253. Scarr E and Dean B. (2008) Muscarinic receptors: do they have a role in the pathology and treatment of schizophrenia? J Neurochem 107: 1188-95 [PMID:18957051] 
254. Schrage R, Holze J, Klöckner J, Balkow A, Klause AS, Schmitz AL, De Amici M, Kostenis E, Tränkle C and Holzgrabe U et al.. (2014) New insight into active muscarinic receptors with the novel radioagonist [ $\left.{ }^{3} \mathrm{H}\right]$ iperoxo. Biochem Pharmacol 90: 307-19 [PMID:24863257]

255. Schrage R, Seemann WK, Klöckner J, Dallanoce C, Racké K, Kostenis E, De Amici M, Holzgrabe U and Mohr K. (2013) Agonists with supraphysiological efficacy at the muscarinic M2 ACh receptor. Br J Pharmacol 169: 357-70 [PMID:23062057]

256. Seeger T, Fedorova I, Zheng F, Miyakawa T, Koustova E, Gomeza J, Basile AS, Alzheimer C and Wess J. (2004) M2 muscarinic acetylcholine receptor knock-out mice show deficits in behavioral flexibility, working memory, and hippocampal plasticity. J Neurosci 24: 10117-27 [PMID:15537882]

257. Sen AP and Bhattacharya SK. (1991) Thermic response of selective muscarinic agonists and antagonists in rat. Indian J Exp Biol 29: 131-5 [PMID:1869296]

258. Shannon HE, Bymaster FP, Calligaro DO, Greenwood B, Mitch CH, Sawyer BD, Ward JS, Wong DT, Olesen PH and Sheardown MJ et al.. (1994) Xanomeline: a novel muscarinic receptor agonist with functional selectivity for M1 receptors. J Pharmacol Exp Ther 269: 271-81 [PMID:7909557]

259. Shapiro RA, Scherer NM, Habecker BA, Subers EM and Nathanson NM. (1988) Isolation, sequence, and functional expression of the mouse M1 muscarinic acetylcholine receptor gene. $J$ Biol Chem 263: 18397-403 [PMID:2848036]

260. Sheffler DJ, Williams R, Bridges TM, Xiang Z, Kane AS, Byun NE, Jadhav S, Mock MM, Zheng F and Lewis LM et al.. (2009) A novel selective muscarinic acetylcholine receptor subtype 1 antagonist reduces seizures without impairing hippocampus-dependent learning. Mol Pharmacol 76: 356-68 [PMID:19407080]

261. Shida T, Tokunaga A, Kondo E, Ueda Y, Ohno K, Saika T, Kiyama H and Tohyama M. (1993) Expression of muscarinic and nicotinic receptor mRNA in the salivary gland of rats: a study by in situ hybridization histochemistry. Brain Res Mol Brain Res 17: 335-9 [PMID:8510505]

262. Shinoe T, Matsui M, Taketo MM and Manabe T. (2005) Modulation of synaptic plasticity by physiological activation of M1 muscarinic acetylcholine receptors in the mouse hippocampus. $J$ Neurosci 25: 11194-200 [PMID:16319319]

263. Sinha S, Gupta S, Malhotra S, Krishna NS, Meru AV, Babu V, Bansal V, Garg M, Kumar N and Chugh A et al.. (2010) AE9C90CB: a novel, bladder-selective muscarinic receptor antagonist for the treatment of overactive bladder. Br J Pharmacol 160: 1119-27 [PMID:20590605]

264. Smith CM and Wallis RM. (1997) Characterisation of [3H]-darifenacin as a novel radioligand for the study of muscarinic M3 receptors. J Recept Signal Transduct Res 17: 177-84 [PMID:9029489]

265. Sowell Sr JW, Tang Y, Valli MJ, Chapman Jr JM, Usher LA, Vaughan CM and Kosh JW. (1992) Synthesis and cholinergic properties of bis[[(dimethylamino)methyl]furanyl] analogues of ranitidine. J Med Chem 35: 1102-8 [PMID:1552502]

266. Spalding TA, Ma JN, Ott TR, Friberg M, Bajpai A, Bradley SR, Davis RE, Brann MR and Burstein ES. (2006) Structural requirements of transmembrane domain 3 for activation by the M1 muscarinic receptor agonists AC-42, AC-260584, clozapine, and N-desmethylclozapine: evidence for three distinct modes of receptor activation. Mol Pharmacol 70: 1974-83 [PMID:16959945]

267. Spalding TA, Trotter C, Skjaerbaek N, Messier TL, Currier EA, Burstein ES, Li D, Hacksell U and Brann MR. (2002) Discovery of an ectopic activation site on the M(1) muscarinic receptor. Mol Pharmacol 61: 1297-302 [PMID:12021390]

268. Stahl E and Ellis J. (2010) Novel allosteric effects of amiodarone at the muscarinic M5 receptor. J Pharmacol Exp Ther 334: 214-22 [PMID:20348203]

269. Stanton T, Bolden-Watson C, Cusack B and Richelson E. (1993) Antagonism of the five cloned human muscarinic cholinergic receptors expressed in CHO-K1 cells by antidepressants and antihistaminics. Biochem Pharmacol 45: 2352-4 [PMID:8100134]

270. Stein R, Pinkas-Kramarski R and Sokolovsky M. (1988) Cloned M1 muscarinic receptors mediate both adenylate cyclase inhibition and phosphoinositide turnover. EMBO J 7: 3031-5 [PMID:2846274]

271. Steinfeld T, Mammen M, Smith JA, Wilson RD and Jasper JR. (2007) A novel multivalent ligand that bridges the allosteric and orthosteric binding sites of the M2 muscarinic receptor. Mol Pharmacol 72: 291-302 [PMID:17478612]

272. Stengel PW and Cohen ML. (2002) Muscarinic receptor knockout mice: role of muscarinic acetylcholine receptors $\mathrm{M}(2), \mathrm{M}(3)$, and $\mathrm{M}(4)$ in carbamylcholine-induced gallbladder contractility. J Pharmacol Exp Ther 301: 643-50 [PMID:11961069]

273. Stengel PW, Gomeza J, Wess J and Cohen ML. (2000) M(2) and M(4) receptor knockout mice: muscarinic receptor function in cardiac and smooth muscle in vitro. J Pharmacol Exp Ther 292: 877-85 [PMID:10688600]

274. Stengel PW, Yamada M, Wess J and Cohen ML. (2002) M(3)-receptor knockout mice: muscarinic receptor function in atria, stomach fundus, urinary bladder, and trachea. Am J Physiol Regul Integr Comp Physiol 282: R1443-9 [PMID:11959688] 
275. Stocks MJ, Alcaraz L, Bailey A, Bowers K, Donald D, Edwards H, Hunt F, Kindon N, Pairaudeau $\mathrm{G}$ and Theaker J et al.. (2010) The discovery of new spirocyclic muscarinic M3 antagonists. Bioorg Med Chem Lett 20: 7458-61 [PMID:21036043]

276. Struckmann N, Schwering S, Wiegand S, Gschnell A, Yamada M, Kummer W, Wess J and Haberberger RV. (2003) Role of muscarinic receptor subtypes in the constriction of peripheral airways: studies on receptor-deficient mice. Mol Pharmacol 64: 1444-51 [PMID:14645675]

277. Sundaram K, Murugaian J, Watson M and Sapru H. (1989) M2 muscarinic receptor agonists produce hypotension and bradycardia when injected into the nucleus tractus solitarii. Brain Res 477: 358-62 [PMID:2467726]

278. Sur C, Mallorga PJ, Wittmann M, Jacobson MA, Pascarella D, Williams JB, Brandish PE, Pettibone DJ, Scolnick EM and Conn PJ. (2003) N-desmethylclozapine, an allosteric agonist at muscarinic 1 receptor, potentiates N-methyl-D-aspartate receptor activity. Proc Natl Acad Sci USA 100: 13674-9 [PMID:14595031]

279. Suzuki T, Fujimoto K, Oohata H and Kawashima K. (1988) Presynaptic M1 muscarinic receptor modulates spontaneous release of acetylcholine from rat basal forebrain slices. Neurosci Lett 84: 209-12 [PMID:3340327]

280. Sykes DA, Dowling MR, Leighton-Davies J, Kent TC, Fawcett L, Renard E, Trifilieff A and Charlton SJ. (2012) The Influence of receptor kinetics on the onset and duration of action and the therapeutic index of NVA237 and tiotropium. J Pharmacol Exp Ther 343: 520-8 [PMID:22854200]

281. Takagi N, Miyake-Takagi K, Takagi K, Tamura H and Takeo S. (2002) Altered extracellular signal-regulated kinase signal transduction by the muscarinic acetylcholine and metabotropic glutamate receptors after cerebral ischemia. J Biol Chem 277: 6382-90 [PMID:11714707]

282. Takeuchi T, Fujinami K, Goto H, Fujita A, Taketo MM, Manabe T, Matsui M and Hata F. (2005) Roles of M2 and M4 muscarinic receptors in regulating acetylcholine release from myenteric neurons of mouse ileum. J Neurophysiol 93: 2841-8 [PMID:15574798]

283. Tanis SP, Plewe MB, Johnson TW, Butler SL, Dalvie D, DeLisle D, Dress KR, Hu Q, Huang B and Kuehler JE et al.. (2010) Azaindole N-methyl hydroxamic acids as HIV-1 integrase inhibitors-II. The impact of physicochemical properties on ADME and PK. Bioorg Med Chem Lett 20: 7429-34 [PMID:21036042]

284. Tarr JC, Turlington ML, Reid PR, Utley TJ, Sheffler DJ, Cho HP, Klar R, Pancani T, Klein MT and Bridges TM et al.. (2012) Targeting selective activation of M(1) for the treatment of Alzheimer's disease: further chemical optimization and pharmacological characterization of the M(1) positive allosteric modulator ML169. ACS Chem Neurosci 3: 884-95 [PMID:23173069]

285. Tautermann CS, Kiechle T, Seeliger D, Diehl S, Wex E, Banholzer R, Gantner F, Pieper MP and Casarosa P. (2013) Molecular basis for the long duration of action and kinetic selectivity of tiotropium for the muscarinic M3 receptor. J Med Chem 56: 8746-56 [PMID:24088171]

286. ten Berge RE, Zaagsma J and Roffel AF. (1996) Muscarinic inhibitory autoreceptors in different generations of human airways. Am J Respir Crit Care Med 154: 43-9 [PMID:8680697]

287. Thal DM, Sun B, Feng D, Nawaratne V, Leach K, Felder CC, Bures MG, Evans DA, Weis WI and Bachhawat P et al.. (2016) Crystal structures of the M1 and M4 muscarinic acetylcholine receptors. Nature 531: 335-40 [PMID:26958838]

288. Thomas RL, Mistry R, Langmead CJ, Wood MD and Challiss RA. (2008) G protein coupling and signaling pathway activation by $\mathrm{m} 1$ muscarinic acetylcholine receptor orthosteric and allosteric agonists. J Pharmacol Exp Ther 327: 365-74 [PMID:18664591]

289. Thomsen M, Woldbye DP, Wörtwein G, Fink-Jensen A, Wess J and Caine SB. (2005) Reduced cocaine self-administration in muscarinic M5 acetylcholine receptor-deficient mice. J Neurosci 25: 8141-9 [PMID:16148222]

290. Tobin AB and Budd DC. (2003) The anti-apoptotic response of the Gq/11-coupled muscarinic receptor family. Biochem Soc Trans 31: 1182-5 [PMID:14641022]

291. Tobin G, Giglio D and Götrick B. (2002) Studies of muscarinic receptor subtypes in salivary gland function in anaesthetized rats. Auton Neurosci 100: 1-9 [PMID:12422954]

292. Trendelenburg AU, Gomeza J, Klebroff W, Zhou H and Wess J. (2003) Heterogeneity of presynaptic muscarinic receptors mediating inhibition of sympathetic transmitter release: a study with M2- and M4-receptor-deficient mice. Br J Pharmacol 138: 469-80 [PMID:12569072]

293. Tränkle C, Dittmann A, Schulz U, Weyand O, Buller S, Jöhren K, Heller E, Birdsall NJ, Holzgrabe $\mathrm{U}$ and Ellis J et al.. (2005) Atypical muscarinic allosteric modulation: cooperativity between modulators and their atypical binding topology in muscarinic M2 and M2/M5 chimeric receptors. Mol Pharmacol 68: 1597-610 [PMID:16157694]

294. Tränkle C, Weyand O, Voigtländer U, Mynett A, Lazareno S, Birdsall NJ and Mohr K. (2003) Interactions of orthosteric and allosteric ligands with [3H]dimethyl-W84 at the common allosteric site of muscarinic M2 receptors. Mol Pharmacol 64: 180-90 [PMID:12815174]

295. Tseng J, Erbe CB, Kwitek AE, Jacob HJ, Popper P and Wackym PA. (2002) Radiation hybrid mapping of five muscarinic acetylcholine receptor subtype genes in Rattus norvegicus. Hear Res 174: 86-92 [PMID:12433399] 
296. Tyagi S, Tyagi P, Van-le S, Yoshimura N, Chancellor MB and de Miguel F. (2006) Qualitative and quantitative expression profile of muscarinic receptors in human urothelium and detrusor. $J$ Urol 176: 1673-8 [PMID:16952712]

297. Tzavara ET, Bymaster FP, Felder CC, Wade M, Gomeza J, Wess J, McKinzie DL and Nomikos GG. (2003) Dysregulated hippocampal acetylcholine neurotransmission and impaired cognition in M2, M4 and M2/M4 muscarinic receptor knockout mice. Mol Psychiatry 8: 673-9 [PMID:12874603]

298. Valant C, Felder CC, Sexton PM and Christopoulos A. (2012) Probe dependence in the allosteric modulation of a G protein-coupled receptor: implications for detection and validation of allosteric ligand effects. Mol Pharmacol 81: 41-52 [PMID:21989256]

299. Valant C, Gregory KJ, Hall NE, Scammells PJ, Lew MJ, Sexton PM and Christopoulos A. (2008) A novel mechanism of $\mathrm{G}$ protein-coupled receptor functional selectivity. Muscarinic partial agonist McN-A-343 as a bitopic orthosteric/allosteric ligand. J Biol Chem 283: 29312-21 [PMID:18723515]

300. Valuskova P, Farar V, Forczek S, Krizova I and Myslivecek J. (2018) Autoradiography of ${ }^{3} \mathrm{H}$ pirenzepine and ${ }^{3} \mathrm{H}-\mathrm{AFDX}-384$ in Mouse Brain Regions: Possible Insights into $\mathrm{M}_{1}, \mathrm{M}_{2}$, and $\mathrm{M}_{4}$ Muscarinic Receptors Distribution. Front Pharmacol 9: 124 [PMID:29515448]

301. van Koppen CJ and Kaiser B. (2003) Regulation of muscarinic acetylcholine receptor signaling. Pharmacol Ther 98: 197-220 [PMID:12725869]

302. Vilaró MT, Palacios JM and Mengod G. (1994) Multiplicity of muscarinic autoreceptor subtypes? Comparison of the distribution of cholinergic cells and cells containing mRNA for five subtypes of muscarinic receptors in the rat brain. Brain Res Mol Brain Res 21: 30-46 [PMID:8164520]

303. Vuckovic Z, Gentry PR, Berizzi AE, Hirata K, Varghese S, Thompson G, van der Westhuizen ET, Burger WAC, Rahmani R and Valant C et al.. (2019) Crystal structure of the $\mathrm{M}_{5}$ muscarinic acetylcholine receptor. Proc Natl Acad Sci USA 116: 26001-26007 [PMID:31772027]

304. Wackym PA, Chen CT, Ishiyama A, Pettis RM, López IA and Hoffman L. (1996) Muscarinic acetylcholine receptor subtype mRNAs in the human and rat vestibular periphery. Cell Biol Int 20: 187-92 [PMID:8673067]

305. Waelbroeck M, De Neef P, Domenach V, Vandermeers-Piret MC and Vandermeers A. (1996) Binding of the labelled muscarinic toxin 125I-MT1 to rat brain muscarinic M1 receptors. Eur J Pharmacol 305: 187-92 [PMID:8813552]

306. Wang H, Ng K, Hayes D, Gao X, Forster G, Blaha C and Yeomans J. (2004) Decreased amphetamine-induced locomotion and improved latent inhibition in mice mutant for the M5 muscarinic receptor gene found in the human 15q schizophrenia region.

Neuropsychopharmacology 29: 2126-39 [PMID:15213703]

307. Wang SZ and el-Fakahany EE. (1993) Application of transfected cell lines in studies of functional receptor subtype selectivity of muscarinic agonists. J Pharmacol Exp Ther 266: 237-43 [PMID:7687290]

308. Wang SZ, Lee SY, Zhu SZ and el-Fakahany EE. (1996) Differential coupling of m1, m3, and m5 muscarinic receptors to activation of neuronal nitric oxide synthase. Pharmacology 53: 271-80 [PMID:8990485]

309. Wang Z, Shi H and Wang H. (2004) Functional M3 muscarinic acetylcholine receptors in mammalian hearts. Br J Pharmacol 142: 395-408 [PMID:15148264]

310. Watson J, Brough S, Coldwell MC, Gager T, Ho M, Hunter AJ, Jerman J, Middlemiss DN, Riley GJ and Brown AM. (1998) Functional effects of the muscarinic receptor agonist, xanomeline, at 5HT1 and 5-HT2 receptors. Br J Pharmacol 125: 1413-20 [PMID:9884068]

311. Watson M, Roeske WR, Johnson PC and Yamamura HI. (1984) [3H]Pirenzepine identifies putative M1 muscarinic receptors in human stellate ganglia. Brain Res 290: 179-82 [PMID:6546354]

312. Watson N, Daniels DV, Ford AP, Eglen RM and Hegde SS. (1999) Comparative pharmacology of recombinant human M3 and M5 muscarinic receptors expressed in CHO-K1 cells. $\mathrm{BrJ}$ Pharmacol 127: 590-6 [PMID:10385263]

313. Watt ML, Schober DA, Hitchcock S, Liu B, Chesterfield AK, McKinzie D and Felder CC. (2011) Pharmacological characterization of LY593093, an M1 muscarinic acetylcholine receptorselective partial orthosteric agonist. J Pharmacol Exp Ther 338: 622-32 [PMID:21558436]

314. Weber S, Thiele H, Mir S, Toliat MR, Sozeri B, Reutter H, Draaken M, Ludwig M, Altmüller J and Frommolt P et al.. (2011) Muscarinic Acetylcholine Receptor M3 Mutation Causes Urinary Bladder Disease and a Prune-Belly-like Syndrome. Am J Hum Genet 89: 668-74 [PMID:22077972]

315. Wei HB, Roeske WR, Lai J, Wanibuchi F, Hidaka K, Usuda S and Yamamura HI. (1992) Pharmacological characterization of a novel muscarinic partial agonist, YM796, in transfected cells expressing the $\mathrm{m} 1$ or $\mathrm{m} 2$ muscarinic receptor gene. Life Sci 50: 355-63 [PMID:1310135]

316. Weiner DM, Levey AI and Brann MR. (1990) Expression of muscarinic acetylcholine and dopamine receptor mRNAs in rat basal ganglia. Proc Natl Acad Sci USA 87: 7050-4 [PMID:2402490] 
317. Wess J. (2003) Novel insights into muscarinic acetylcholine receptor function using gene targeting technology. Trends Pharmacol Sci 24: 414-20 [PMID:12915051]

318. Wess J. (2004) Muscarinic acetylcholine receptor knockout mice: novel phenotypes and clinical implications. Annu Rev Pharmacol Toxicol 44: 423-50 [PMID:14744253]

319. Wess J. (1996) Molecular biology of muscarinic acetylcholine receptors. Crit Rev Neurobiol 10: 69-99 [PMID:8853955]

320. Wess J, Duttaroy A, Zhang W, Gomeza J, Cui Y, Miyakawa T, Bymaster FP, McKinzie L, Felder CC and Lamping KG et al.. (2003) M1-M5 muscarinic receptor knockout mice as novel tools to study the physiological roles of the muscarinic cholinergic system. Recept Channels 9: 279-90 [PMID:12893539]

321. Wess J, Eglen RM and Gautam D. (2007) Muscarinic acetylcholine receptors: mutant mice provide new insights for drug development. Nat Rev Drug Discov 6: 721-33 [PMID:17762886]

322. Wess J, Lambrecht G, Mutschler E, Brann MR and Dörje F. (1991) Selectivity profile of the novel muscarinic antagonist UH-AH 37 determined by the use of cloned receptors and isolated tissue preparations. BrJ Pharmacol 102: 246-50 [PMID:2043926]

323. Widzowski DV, Bialobok P, Kucera KE, Mihut R, Sitar S, Knowles M, Stagnitto M, Howell A, McCreedy S, Machulskis A, Gordon J, Marler M, Wu ESC, Mullen G, Triggle DJ and Blosser J. (1997) Development of a pharmacological target profile for muscarinic agonists. Drug Development Research 40: 117-132

324. Willmy-Matthes P, Leineweber K, Wangemann T, Silber RE and Brodde OE. (2003) Existence of functional M3-muscarinic receptors in the human heart. Naunyn Schmiedebergs Arch Pharmacol 368: 316-9 [PMID:14520506]

325. Wilson PS, Khimenko PL, Barnard JW, Moore TM and Taylor AE. (1995) Muscarinic agonists and antagonists cause vasodilation in isolated rat lung. J Appl Physiol 78: 1404-11 [PMID:7615448]

326. Woo SH, Lee BH, Kwon KI and Lee CO. (2005) Excitatory effect of M1 muscarinic acetylcholine receptor on automaticity of mouse heart. Arch Pharm Res 28: 930-5 [PMID:16178419]

327. Wood IC, Roopra A, Harrington C and Buckley NJ. (1995) Structure of the m4 cholinergic muscarinic receptor gene and its promoter. J Biol Chem 270: 30933-40 [PMID:8537349]

328. Wood MD, Murkitt KL, Ho M, Watson JM, Brown F, Hunter AJ and Middlemiss DN. (1999) Functional comparison of muscarinic partial agonists at muscarinic receptor subtypes hM1, hM2, hM3, hM4 and hM5 using microphysiometry. Br J Pharmacol 126: 1620-4 [PMID:10323594]

329. Wotta DR, Wattenberg EV, Langason RB and el-Fakahany EE. (1998) M1, M3 and M5 muscarinic receptors stimulate mitogen-activated protein kinase. Pharmacology 56: 175-86 [PMID:9566019]

330. Xie G, Drachenberg C, Yamada M, Wess J and Raufman JP. (2005) Cholinergic agonist-induced pepsinogen secretion from murine gastric chief cells is mediated by M1 and M3 muscarinic receptors. Am J Physiol Gastrointest Liver Physiol 289: G521-9 [PMID:15933222]

331. Yamada M, Basile AS, Fedorova I, Zhang W, Duttaroy A, Cui Y, Lamping KG, Faraci FM, Deng CX and Wess J. (2003) Novel insights into M5 muscarinic acetylcholine receptor function by the use of gene targeting technology. Life Sci 74: 345-53 [PMID:14607263]

332. Yamada M, Lamping KG, Duttaroy A, Zhang W, Cui Y, Bymaster FP, McKinzie DL, Felder CC, Deng CX and Faraci FM et al.. (2001) Cholinergic dilation of cerebral blood vessels is abolished in M(5) muscarinic acetylcholine receptor knockout mice. Proc Natl Acad Sci USA 98: 14096101 [PMID:11707605]

333. Yamada M, Miyakawa T, Duttaroy A, Yamanaka A, Moriguchi T, Makita R, Ogawa M, Chou CJ, Xia B and Crawley JN et al.. (2001) Mice lacking the M3 muscarinic acetylcholine receptor are hypophagic and lean. Nature 410: 207-12 [PMID:11242080]

334. Yamashita Y, Tanaka K, Asano T, Yamakawa N, Kobayashi D, Ishihara T, Hanaya K, Shoji M, Sugai T and Wada M et al.. (2014) Synthesis and biological comparison of enantiomers of mepenzolate bromide, a muscarinic receptor antagonist with bronchodilatory and antiinflammatory activities. Bioorg Med Chem 22: 3488-97 [PMID:24844758]

335. Yao XC, Wang TX, Chen HZ, Gao WB, Fowler AG, Raussendorf R, Chen ZB, Liu NL, Lu CY and Deng YJ et al.. (2012) Experimental demonstration of topological error correction. Nature 482: 489-94 [PMID:22358838]

336. Yasuda RP, Ciesla W, Flores LR, Wall SJ, Li M, Satkus SA, Weisstein JS, Spagnola BV and Wolfe BB. (1993) Development of antisera selective for $\mathrm{m} 4$ and $\mathrm{m} 5$ muscarinic cholinergic receptors: distribution of $\mathrm{m} 4$ and $\mathrm{m} 5$ receptors in rat brain. Mol Pharmacol 43: 149-57 [PMID:8429821]

337. Yeomans J, Forster G and Blaha C. (2001) M5 muscarinic receptors are needed for slow activation of dopamine neurons and for rewarding brain stimulation. Life Sci 68: 2449-56 [PMID:11392612]

338. Zawalich WS, Zawalich KC, Tesz GJ, Taketo MM, Sterpka J, Philbrick W and Matsui M. (2004) Effects of muscarinic receptor type 3 knockout on mouse islet secretory responses. Biochem Biophys Res Commun 315: 872-6 [PMID:14985093]

339. Zhang Q, Pacheco MA and Doupnik CA. (2002) Gating properties of GIRK channels activated by 
Galpha(o)- and Galpha(i)-coupled muscarinic $\mathrm{m} 2$ receptors in Xenopus oocytes: the role of receptor precoupling in RGS modulation. J Physiol (Lond.) 545: 355-73 [PMID:12456817]

340. Zhang W, Basile AS, Gomeza J, Volpicelli LA, Levey AI and Wess J. (2002) Characterization of central inhibitory muscarinic autoreceptors by the use of muscarinic acetylcholine receptor knock-out mice. J Neurosci 22: 1709-17 [PMID:11880500]

341. Zhang W, Yamada M, Gomeza J, Basile AS and Wess J. (2002) Multiple muscarinic acetylcholine receptor subtypes modulate striatal dopamine release, as studied with M1-M5 muscarinic receptor knock-out mice. J Neurosci 22: 6347-52 [PMID:12151512]

342. Zhang X, Hernandez MR, Yang H and Erickson K. (1995) Expression of muscarinic receptor subtype mRNA in the human ciliary muscle. Invest Ophthalmol Vis Sci 36: 1645-57 [PMID:7541396]

343. Zhang Y, Dyck RH, Hamilton SE, Nathanson NM and Yan J. (2005) Disrupted tonotopy of the auditory cortex in mice lacking M1 muscarinic acetylcholine receptor. Hear Res 201: 145-55 [PMID:15721569]

344. Zhang Y, Hamilton SE, Nathanson NM and Yan J. (2006) Decreased input-specific plasticity of the auditory cortex in mice lacking M1 muscarinic acetylcholine receptors. Cereb Cortex 16: 1258-65 [PMID:16292003]

345. Zhou C, Fryer AD and Jacoby DB. (2001) Structure of the human M(2) muscarinic acetylcholine receptor gene and its promoter. Gene 271: 87-92 [PMID:11410369] 